\title{
Comparison of Neurodegenerative Pathology in Transgenic Mice Overexpressing V717F $\beta$-Amyloid Precursor Protein and Alzheimer's Disease
}

\author{
Eliezer Masliah,, ${ }^{1,2}$ Abbyann Sisk, ${ }^{1}$ Margaret Mallory, ${ }^{1}$ Lennart Mucke, ${ }^{3}$ Dale Schenk, ${ }^{4}$ and Dora Games ${ }^{4}$ \\ Departments of ${ }^{1}$ Neurosciences and ${ }^{2}$ Pathology, University of California-San Diego, La Jolla, California 92093-0624, \\ ${ }^{3}$ Molecular Neurobiology Program, The Gladstone Institute, San Francisco, California 94141-9100, and ${ }^{4}$ Athena \\ Neurosciences, Inc., South San Francisco, California 94080
}

\begin{abstract}
Overexpression of mutated human amyloid precursor protein $(\mathrm{hAPP} 717 \mathrm{~V} \rightarrow \mathrm{F}$ ) under control of platelet-derived growth factor promoter (PDAPP minigene) in transgenic (tg) mice results in neurodegenerative changes similar to Alzheimer's disease (AD). To clarify the pathology of these mice, we studied images derived from laser scanning confocal and electron microscopy and performed comparisons between PDAPP tg mice and AD. Similar to AD, neuritic plaques in PDAPP tg mouse contained a dense amyloid core surrounded by anti-hAPP- and antineurofilament-immunoreactive dystrophic neurites and astroglial cells. Neurons were found in close proximity to plaques in PDAPP tg mice and, to a lesser extent, in AD. In PDAPP tg mice, and occasionally in AD, neuronal processes contained fine intracellular amyloid fibrils in close proximity to the rough endoplasmic reticulum, coated vesicles, and electron-dense material. Extracellular amyloid fibrils $(9-11 \mathrm{~nm}$ in diameter)
\end{abstract}

were abundant in PDAPP tg and were strikingly similar to those observed in AD. Dystrophic neurites in plaques of PDAPP tg mouse and $A D$ formed synapses and contained many dense multilaminar bodies and neurofilaments $(10 \mathrm{~nm})$. Apoptotic-like figures were present in the tg mice. No paired helical filaments have yet been observed in the heterozygote PDAPP $\mathrm{tg}$ mice. In summary, this study shows that PDAPP tg mice develop massive neuritic plaque formation and neuronal degeneration similar to $A D$. These findings show that overproduction of $\mathrm{hAPP} 717 \mathrm{~V} \rightarrow \mathrm{F}$ in tg mice is sufficient to cause not only amyloid deposition, but also many of the complex subcellular degenerative changes associated with $A D$.

Key words: Alzheimer's disease; amyloid precursor protein; transgenic; electron microscopy; confocal microscopy; neurodegeneration
The neurodegenerative process in Alzheimer's disease (AD) is characterized by the progressive and irreversible deafferentation of the limbic system, association neocortex, and basal forebrain (Perry et al., 1977; Hyman et al., 1984; Wilcock et al., 1988; Hof et al., 1990; Palmer and Gershon, 1990; Masliah et al., 1993a), accompanied by neuritic plaque and tangle formation (for review, see Terry et al., 1994). The neuritic plaques in AD contain amyloid $\beta$ protein $(\mathrm{A} \beta)$, which is derived from the amyloid $\beta$ precursor protein (APP) (Selkoe et al., 1988; Selkoe, 1993). Embedded in the amyloid plaque core are dystrophic neurites, as well as reactive astrocytes and microglia (Terry et al., 1964; Terry and Wisniewski, 1970; Dickson et al., 1988; Wisniewski et al., 1989, 1991; Masliah et al., 1991c, 1993b; Frackowiak et al., 1992). The neuritic population in the plaque is mixed, being composed of spherical neurites that contain synaptic proteins and APP (type I), as well as fusiform neurites that contain cytoskeletal proteins and paired helical filaments (PHF; type II) (Dickson et al., 1988; Masliah et al., 1993b, 1994a; Wang and Munoz, 1995). The precise mechanisms by which neuritic plaques are formed and their relationship to the overall neurodegenerative process in $\mathrm{AD}$ are not

Received Jan. 11, 1996; revised June 19, 1996; accepted July 3, 1996.

This work was supported by Athena Neurosciences, Inc. Additional support was provided by National Institutes of Health Grants AG10689 and AG5131 (E.M.) and AG11385 (L.M.). This work was also partially supported by Grant RR04050. We thank Dr. Robert Terry for his valuable comments, and Karen Khan, Ferdie Soriano, Tony Carr, Terry Guido, and Albert Maya for their technical assistance.

Correspondence should be addressed to Dr. E. Masliah, Department of Neurosciences, University of California-San Diego, La Jolla, CA 92093-0624.

Copyright (C) 1996 Society for Neuroscience $0270-6474 / 96 / 165795-17 \$ 05.00 / 0$ yet clear. Increasing evidence indicates that errantly processed APP derivatives may be involved in the pathophysiological process that leads to neurodegeneration and plaque formation in $\mathrm{AD}$ (Sisodia et al., 1990; Golde et al., 1992; Seubert et al., 1992; Mattson et al., 1993; Selkoe, 1993).

To study the events involved in this process in vivo, several transgenic (tg) mice harboring the human APP (hAPP) gene have been developed (Higgins et al., 1994; Mucke et al., 1994; Games et al., 1995a,b). Some of these tg mouse models were designed based on the key observation that a number of APP mutations cosegregate with the familial form of $\mathrm{AD}$ and that these patients have, on autopsy, neuropathological alterations that are indistinguishable from sporadic AD (Chartier-Harlin et al., 1991; Goate et al., 1991; Murrell et al., 1991; Clark and Goate, 1993). Furthermore, it has been demonstrated that the APP717 mutations result in an overproduction of the highly amyloidogenic $\mathrm{A} \beta$ (1-42) relative to other $\mathrm{A} \beta$ peptides (Suzuki et al., 1994). Notably, one APP tg mouse model (PDAPP) was generated recently that exhibits AD-like neuropathology (Games et al., 1995a). This transgene used a platelet-derived growth factor-B chain (PDGF-B) promoter to drive a hAPP minigene (PDAPP) (Games et al., 1995a; Rockenstein et al., 1995) encoding alternatively spliced hAPP that contains the mutation $\mathrm{V} \rightarrow \mathrm{F}$ in position 717 that is associated with familial AD (Chartier-Harlin et al., 1991; Murrell et al., 1991; Clark and Goate, 1993). This resulted in an age- and brain region-dependent development of typical amyloid plaques, dystrophic neurites, loss of presynaptic terminals, astrocytosis, and microgliosis (Games et al., 1995a,b). More recent studies 
designed to characterize the transgene better have shown that the PDAPP minigene contains three modified hAPP introns that differ from the corresponding authentic hAPP gene introns by large deletions (introns 6 and 8) or insertion of four nucleotides (intron 7) (Rockenstein et al., 1995). Furthermore, PDAPP tg mice had four- to sixfold higher levels of total APP mRNA compared with non-tg mice or humans, whereas their endogenous mouse APP mRNA levels were reduced. This resulted in a high ratio of mRNA encoding mutated hAPP versus wild-type mouse APP (Rockenstein et al., 1995).

To clarify more fully the pathology of the heterozygous PDAPP $\operatorname{tg}$ mice at the ultrastructural level and to determine the fine ultrastructural differences and similarities between the tg mice and $\mathrm{AD}$, we studied serially reconstructed images derived from the laser scanning confocal microscopy and electron microscopy.

\section{MATERIALS AND METHODS}

Mouse and human tissues. The heterozygous tg mice analyzed in this study were from the previously established line PDAPP-109 $(n=4$, age 8 months; $n=3$, age 12 months) (Games et al., 1995a). Age-matched non-tg littermates derived from the PDAPP ( $n=4$, age 8 months; $n=3$, age 12 months) lines were used as controls. Mice were derived over several generations from hybrid backgrounds representing combinations of C57BL/6 + DBA + Swiss-Webster strains. The right hemibrain was processed for electron microscopy, and the left half was processed for double-immunolabeling/laser scanning confocal microscopy. For ultrastructural comparisons with the tg material, epoxy-embedded blocks from the frontal cortex biopsies of two clinically and histopathologically confirmed $\mathrm{AD}$ cases were examined for the present study. These were prepared in the 1960s at the Albert Einstein College of Medicine. The material was fixed in veronal- or chromate-buffered osmic acid; characteristics of these biopsies are described elsewhere (Terry et al., 1964). For double-immunolabeling/confocal microscopy comparisons with the $\mathrm{tg}$ material, autopsy tissue blocks from the frontal cortex of two AD cases from the Alzheimer Disease Research Center (ADRC) at the University of California-San Diego were placed in $2 \%$ paraformaldehyde-PBS, $\mathrm{pH}$ 7.4 , at $4^{\circ} \mathrm{C}$ overnight and analyzed as described previously (Masliah et al., 1992, 1993b).

Tissue processing. Mice were anesthetized and perfused with cold saline followed by $2 \%$ glutaraldehyde $+2 \%$ paraformaldehyde in $0.15 \mathrm{M}$ cacodylate buffer. Brains were removed and placed in the fixative for $24 \mathrm{hr}$ at $4^{\circ} \mathrm{C}$. After fixation, brains were divided sagittally and blocks $(0.2 \times 0.2$ $\mathrm{cm}$ ) were taken from the frontal cortex and hippocampal region of the right hemibrain for processing and embedding in epon for subsequent ultrastructural analysis as described previously (Masliah et al., 1991a, 1993b,c). The left hemibrain of tg and non-tg mice, as well as tissue blocks from the $\mathrm{AD}$ midfrontal cortex, was serially sectioned at $40 \mu \mathrm{m}$ with the Vibratome 2000 (Technical Products International, St. Louis, MO), and sections were cryoprotected and stored at $-20^{\circ} \mathrm{C}$ as described previously (Masliah et al., 1992, 1993b).

Ultrastructural analysis and immunogold labeling. The epoxy-embedded blocks from the murine and human cases were sectioned with the Reichert Ultracut-E ultramicrotome (Leica, Vienna, Austria), placed on 200-mesh copper grids and stained in saturated ethanol/uranyl acetate and bismuth subnitrate, as described previously (Masliah et al., 1993b,c). From each case, $\sim 10$ sections ( $80 \mathrm{~nm}$ thick) were analyzed with a Zeiss EM10 Electron Microscope at $5000 \times, 10,000 \times, 20,000 \times$, and $50,000 \times$ magnifications to compare the ultrastructural characteristics of neurons, synapses, and plaques between the tg mice and the $\mathrm{AD}$ material. From each case, a total of 60 micrographs (15 at each of the 4 magnifications indicated) were prepared. To determine the relationship among neuritic processes, cellular elements, and amyloid, additional series of 10 sections (each $80 \mathrm{~nm}$ thick) were divided and transferred onto formvar carboncoated slot grids. Serial numbered electron micrographs of selected areas containing neuritic plaques were taken with a Zeiss EM10 electron microscope at a magnification of $3300 \times$ and $5000 \times$ for analysis as described previously (Masliah et al., 1993b). Further analysis of the characteristics of the amyloid fibrils in the plaque core was done by immunogold labeling. Briefly (Deftos et al., 1993), vibratome sections from control and PDAPP tg mice were fixed in $0.25 \%$ glutaraldehyde and $3 \%$ paraformaldehyde in $0.1 \mathrm{M}$ cacodylate buffer, $\mathrm{pH}$ 7.4. Tissues were incubated in $100 \mathrm{~mm}$ glycine in sodium cacodylate buffer followed by brief fixation in $0.1 \%$ osmium tetraoxide. Sections were dehydrated in a graded series of ethanol solutions. From each section, the frontal cortex and hippocampus were dissected and placed in gelatin capsules containing a polymerized layer of LR white (medium grade, Ted Pella, Inc., Redding, CA). Fresh LR white was then added and polymerized for $24 \mathrm{hr}$ in a $55^{\circ} \mathrm{C}$ oven. Blocks were sectioned on an Ultracut E, and thin sections (60-90 $\mathrm{nm})$ were placed on nickel grids coated with a $0.5 \%$ paralodian film. Grids were incubated at room temperature (RT) for 30 min with blocking buffer (TBS $+0.8 \%$ BSA $+0.1 \%$ gelatin $+0.02 \%$ sodium azide), incubated for $12 \mathrm{hr}$ at RT with the biotin-conjugated monoclonal antibody against amyloid $\beta$ protein (1-5) (3D6, Athena Neurosciences, San Francisco, CA), followed by avidin-gold (5 nm, Zymed Laboratories, San Francisco, CA). Grids were then fixed in $2 \%$ glutaraldehyde and postfixed with $2 \%$ uranyl acetate, followed by bismuth subnitrate. Immunogold-labeled grids were examined with a Zeiss EM10 electron microscope. Control experiments were done by incubating grids with avidin-gold in the absence of primary antibody.

Double-immunofluorescent labeling and confocal microscopy. To understand better the relationship between neuronal elements and amyloid in the plaques, vibratome sections from the murine and human cases were first washed in PBS, $\mathrm{pH}$ 7.4, blocked with normal serum, and incubated overnight at $4^{\circ} \mathrm{C}$ with a mixture of the rabbit polyclonal antibody against amyloid $\beta$ protein (R1280, courtesy of Dr. Dennis Selkoe) (Joachim et al., 1989) and with the mouse monoclonal antibody against phosphorylated medium and high molecular weight neurofilaments (SMI312, Sternberger Monoclonals, Baltimore, MD) (Masliah et al., 1993a) as described previously (Masliah et al., 1993a,b). Sections were then incubated with a mixture of FITC-conjugated horse anti-mouse $\operatorname{IgG}(1: 75)$ and Texas Red-conjugated goat anti-rabbit antibody (1:100, Vector Laboratories, Burlingame, CA). The double-immunolabeled sections were transferred to SuperFrost slides (Fisher Scientific, Tustin, CA) and mounted under glass coverslips with antifading media (VectaShield, Vector). All sections were processed simultaneously under the same conditions. The immunofluorescent labeling was done twice to assess the reproducibility of results. Additional comparisons of the spatial relationship among amyloid, dystrophic neurites, and astroglial elements between the PDAPP tg and AD plaques was done by double-immunolabeling with the following pairs of antibodies: (1) anti-glial fibrillary acidic protein (GFAP; Boehringer Mannheim, Indianapolis, IN)/anti-amyloid $\beta$ protein (3D6), and (2) antihAPP (clone 8E5, Athena)/anti-amyloid $\beta$ protein (3D6). After an overnight incubation at $4^{\circ} \mathrm{C}$ in the primary antibodies, the sections were incubated with a mixture of FITC-conjugated horse anti-mouse (1:75, Vector) and Texas Red avidin D (1:75, Vector). The doubleimmunolabeled sections were viewed with a Zeiss $63 \times$ (numerical aperture 1.4) objective on a Zeiss Axiovert 35 microscope with an attached laser confocal scanning system MRC 1024 (Bio-Rad, Wattford, UK) (Masliah et al., 1992, 1993a,b). From each case, five fields within the frontal cortex and five fields within the hippocampal CA1 region were imaged. Serial optical z-sections $(0.2 \mu \mathrm{m}$ in thickness $)$ of the doubleimmunolabeled neuritic plaques were collected from each region using the dual-channel imaging capability of the laser confocal microscope (Masliah et al., 1992, 1993a,b). The Texas Red channel collected the amyloid deposits, and the FITC channel collected the corresponding images of the anti-neurofilament-, hAPP-, and GFAP-immunolabeled elements in the plaques. Each series of optical sections was scanned through a total of $20 \mu \mathrm{m}$, resulting in a complete series composed of $\sim 75-100$ dual optical sections. The digitized video images were processed and stored on $650 \mathrm{MB}$ rewritable optical disk cartridges. Serial optical sections of the neuritic plaques, obtained from the laser confocal microscope, were transferred to a Silicon Graphics Iris 4D/210VGX for visualization of the three-dimensional relationship among the dystrophic neurites and amyloid in the plaques (Masliah et al., 1993b).

\section{RESULTS}

\section{General characteristics of the plaques}

Analysis of a total of 250 neuritic plaques in the frontal cortex (layers 2-3 and 5) and hippocampus (pyramidal cell layer of CA1) of heterozygous PDAPP tg mice $(n=7)$ revealed that at least two general types of plaques could be identified: (1) those containing clusters of dystrophic neurites without an amyloid core (Fig. 1A), and (2) those containing extensive clusters of dystrophic neurites accompanied by one or more amyloid cores (Fig. $1 B-D$ ). Approximately $20 \%$ of the lesions were devoid of amyloid, whereas the 

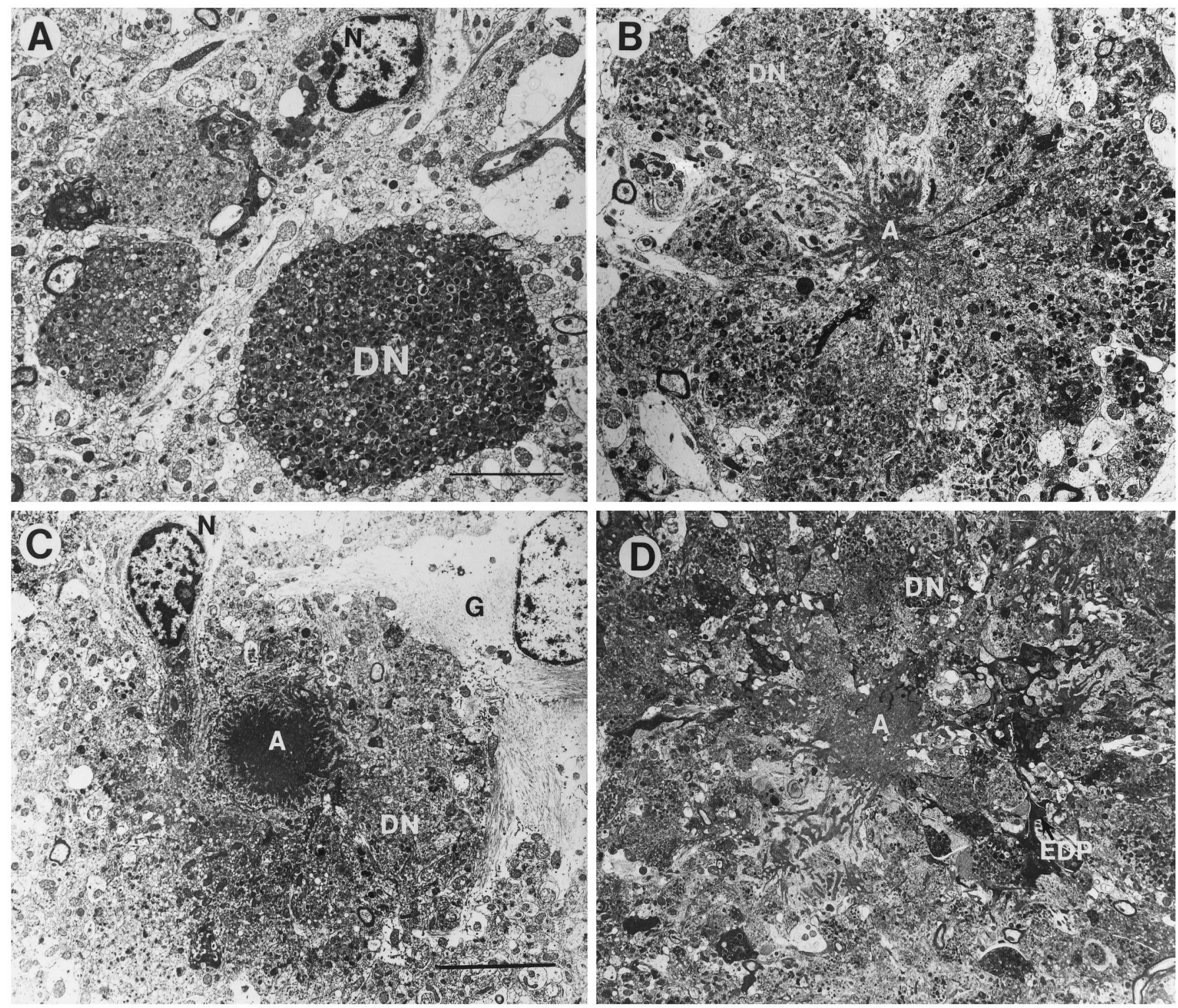

Figure 1. Types of neuritic plaques in the hippocampal CA1 pyramidal cell layer of PDAPP tg mice. $A$, Ultrastructural analysis revealed the presence of clusters of dystrophic neurites $(D N)$ containing abundant electrodense multilaminar bodies. No amyloid was observed in this type of lesion. $N$ indicates the nucleus of cells associated with the plaque. $B, C$, Classical neuritic plaques contained dystrophic neurites $(D N)$, an amyloid core $(A)$, astrocytic glial cells $(G)$, and an associated neuronal cell $(N)$. D, A third type of plaque presented degenerating and dystrophic neurites $(D N)$ in the periphery, and abundant very dense amyloid cores $(A)$ with prominent fusiform electrodense processes $(E D P)$. Scale bar, $15 \mu \mathrm{m}$.

other $80 \%$ were associated with amyloid deposits. At least three subtypes of amyloid-containing neuritic plaques were identified: (1) plaques with abundant dystrophic neurites and scant amyloid bundles (Figs. $1 B, 2 B, E$ ), (2) plaques with abundant dystrophic neurites, abundant amyloid deposition, and some glial cells (Fig. $1 C$ ), and (3) plaques with degenerated electrodense processes, dystrophic neurites, and very dense amyloid deposits (Fig. 1D) surrounded by glial cells. Another notable feature in the PDAPP $\operatorname{tg}$ mice was the presence of neurons in close association with the neuritic plaques (Figs. $1 A, C, 2 B, 3 C, D, 6 A-C$ ). Similar to PDAPP tg, AD cases also displayed clusters of dystrophic neurites (Fig. $2 C, F$ ) with or without amyloid and occasional neuronal cells in close proximity to the neuritic plaques (Fig. $2 C$ ). However, AD neuritic plaques contained more cells with ultrastructural characteristics consistent with microglia (data not shown) than the neuritic plaques of heterozygous PDAPP tg mice. In contrast to the ultrastructural findings in the PDAPP $\operatorname{tg}$ mice, age- and line-matched non-tg littermates $(n=7)$ did not show neuritic alterations or amyloid formation. Only occasional hypertrophic astroglial cells were observed in the CA1 region of the hippocampus (Fig. 4D). Consistent with the ultrastructural findings, immunolabeling with the anti-neurofilament antibody (SMI312) showed a well preserved and organized neuritic structure (Fig. $4 A)$ in the non-tg control mice.

\section{Amyloid deposits in plaques}

Amyloid deposits in PDAPP tg mice were remarkably similar to those observed in $\mathrm{AD}$ (Fig. 5) and were usually associated with anti-neurofilament- and anti-hAPP-immunoreactive dystrophic neurites and neuronal cell bodies. In both PDAPP (Fig. $5 A-C$ ) 

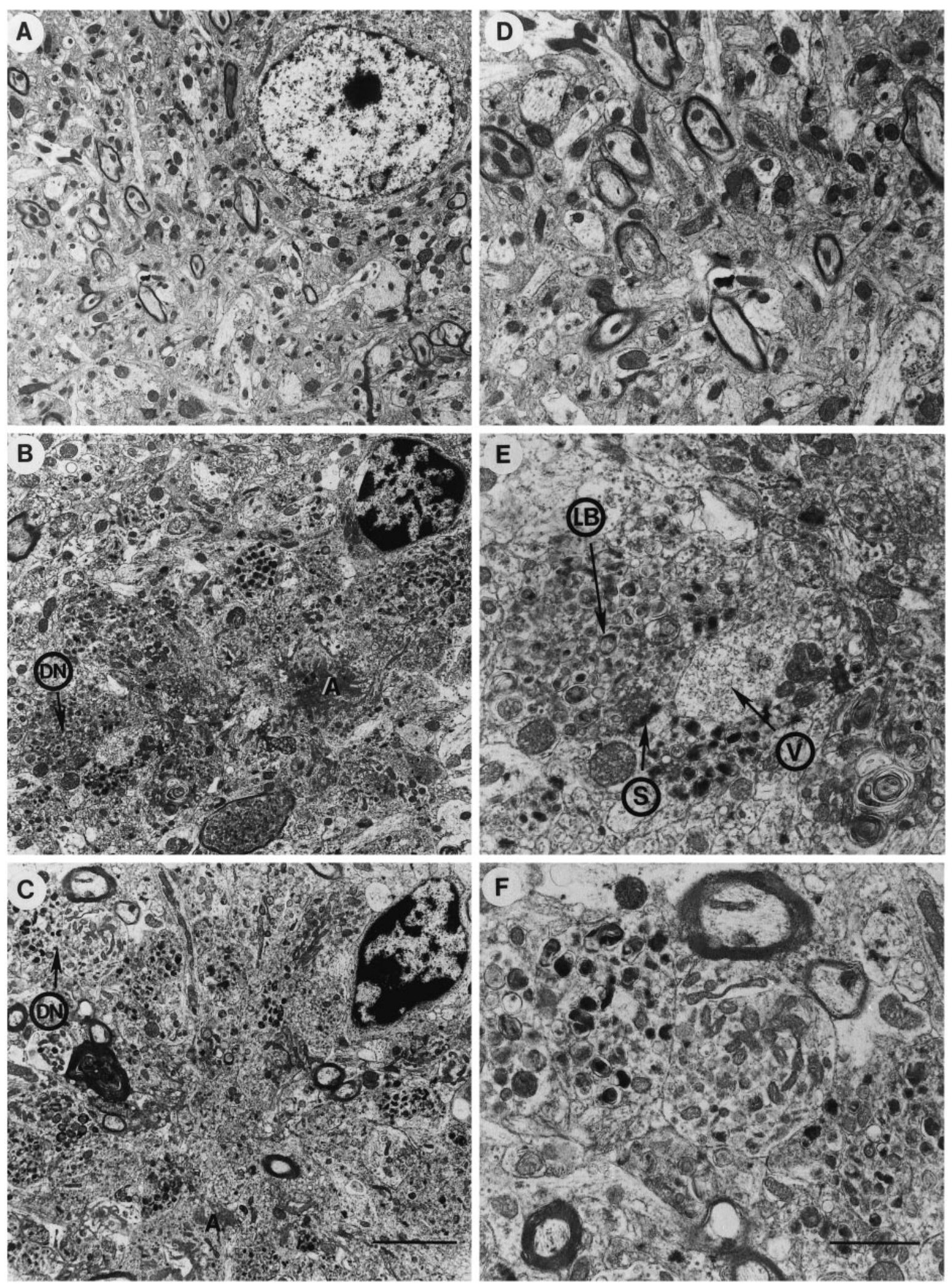

Figure 2. Comparison of neuritic plaques between PDAPP tg mice and AD. A, Low-power view of the frontal cortex in control non-tg mice shows preserved neuronal structure. $B$, Low-power view of a classical neuritic plaque in the frontal cortex of a PDAPP tg mouse shows abundant dystrophic neurites $(D N)$, amyloid deposits $(A)$, and an associated cell that displays chromatin clumps beneath the nuclear envelope. $C$, Low-power view of a classical neuritic plaque in the frontal cortex of an $\mathrm{AD}$ case that displayed abundant dystrophic neurites $(D N)$, amyloid deposits $(A)$, and an associated cell that also presents some nuclear chromatin aggregation. $D$, Higher-power view of the neuropil in the control non-tg mice shows preservation of the neuritic and synaptic structure. $E$, Higher-power view of the dystrophic neurites in the PDAPP tg mouse shows similar electrodense laminar bodies $(L B)$ to the ones observed in $\mathrm{AD}$. The dystrophic neurites made synaptic contacts $(S)$ and contained abundant small vesicles $(V)$. $F$, Higher-power view of a dystrophic neurite in $\mathrm{AD}$ that shows abundant laminar dense bodies and mitochondria. Scale bars: $B, 10 \mu \mathrm{m} ; C, 1.5 \mu \mathrm{m}$. 

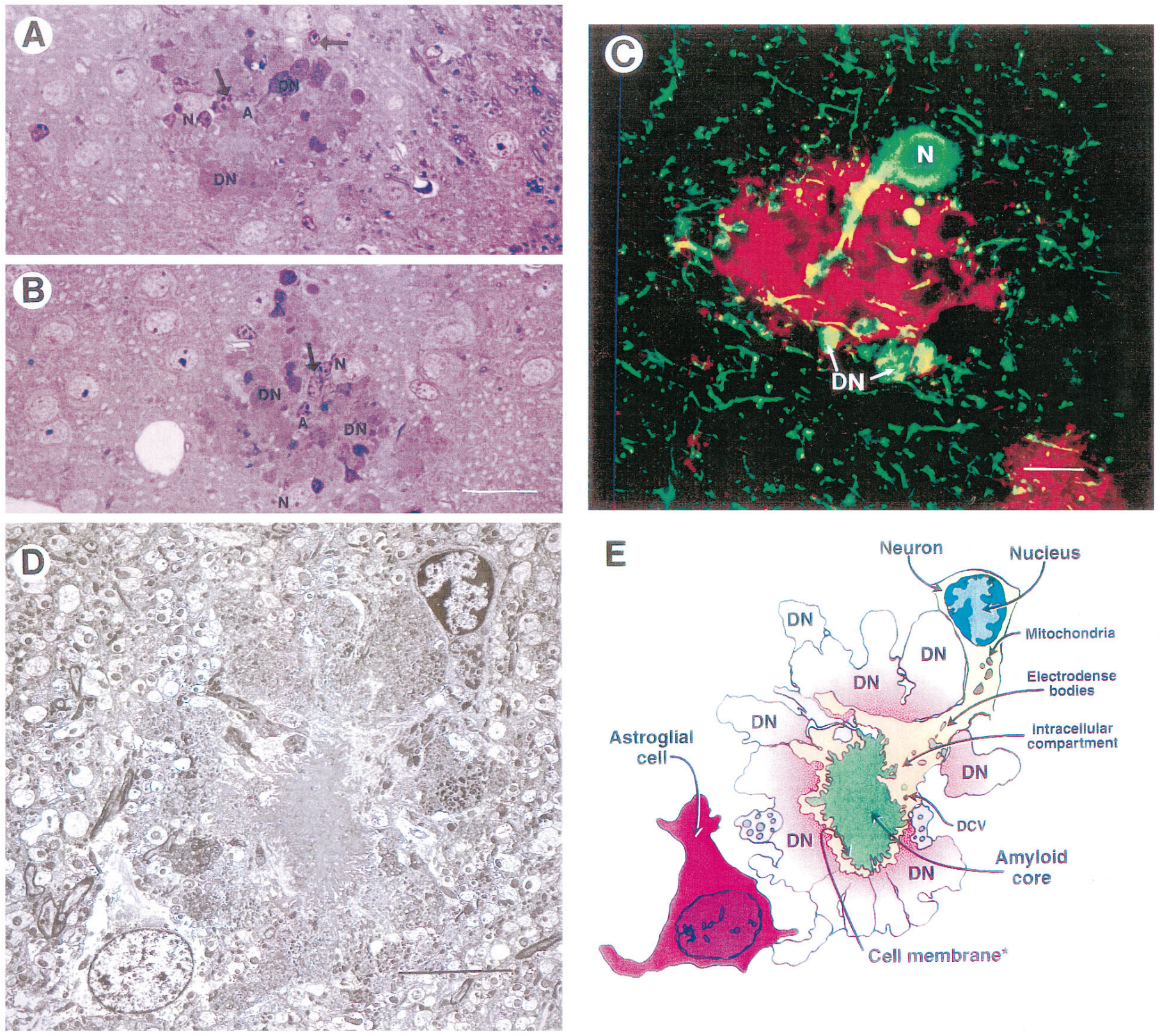

Figure 3. Cellular alterations associated with the neuritic plaque in the PDAPP tg mice. $A, B$, Semithin section $(250 \mathrm{~nm})$ of a neuritic plaque in the hippocampus (pyramidal cell layer) stained with toluidine blue demonstrates dystrophic neurites $(D N)$, amyloid $(A)$, neuronal cell involvement $(N)$, and glial cells (arrows). $C$, The dystrophic neurites $(D N)$ and a neuronal cell body $(N)$ embedded in the plaque were strongly immunoreactive with SMI312, a monoclonal antibody that identifies phosphorylated neurofilaments (green). The amyloid component was immunolabeled with the polyclonal antibody against A $\beta$ R1280 (red). This neuritic plaque was identified in the hippocampus and imaged with the LSCM as described previously (Masliah et al., 1993b). $D$, Electron micrograph of a classical neuritic plaque in the hippocampus shows that these lesions were composed of a prominent neuronal element accompanied by extensive neuritic dystrophy, amyloid deposits, and astroglial cell reaction. $E$, Diagrammatic representation of neuritic plaque illustrated in $D$. Scale bars: $A, 30 \mu \mathrm{m} ; C, 10 \mu \mathrm{m} ; D, 25 \mu \mathrm{m}$.

and $\mathrm{AD}$ (Fig. 5D-F), the dense extracellular amyloid consisted of filaments ranging in diameter from 9 to $11 \mathrm{~nm}$ that were surrounded by cell membranes that were derived from the neuronal elements in the plaque (Figs. $3 D, 5 A-C, 6 A, B, D, E, 7 B, E$ ). Densecore vesicles (neurosecretory type) ranging in diameter from 85 to $250 \mathrm{~nm}$ (Figs. 5A,B, 7C-E) in the cytoplasmic compartment adjacent to the extracellular amyloid fibrils confirmed the neuronal origin of these cellular processes. In addition, the neuronal processes apposed to the extracellular amyloid fibrils contained fine granules (average size of grains was $\sim 5 \mathrm{~nm}$ in diameter)
(Figs. $5 A, C, 7 E$ ). Compared with biopsy material from the $\mathrm{AD}$ cases (Fig. $5 D, E$ ), the plaques in the PDAPP mice (Fig. $5 A, C$ ) contained more dense extracellular amyloid bundles and more abundant fine granular deposits in the cytoplasmic phase of the neuronal processes associated with the plaque (Figs. $5 A, C, 7 D$ ). Consistent with the double-immunolabeling results (Fig. $4 B, E, H$ ) and the ultrastructural findings, the amyloid fibrils in the PDAPP $\operatorname{tg}$ mice were recognized by the anti- $\beta$-amyloid antibody (3D6), as reflected by the labeling of the fibrils by colloidal gold (Fig. $6 F$ ). Cellular processes near the amyloid core displayed fine intracel- 

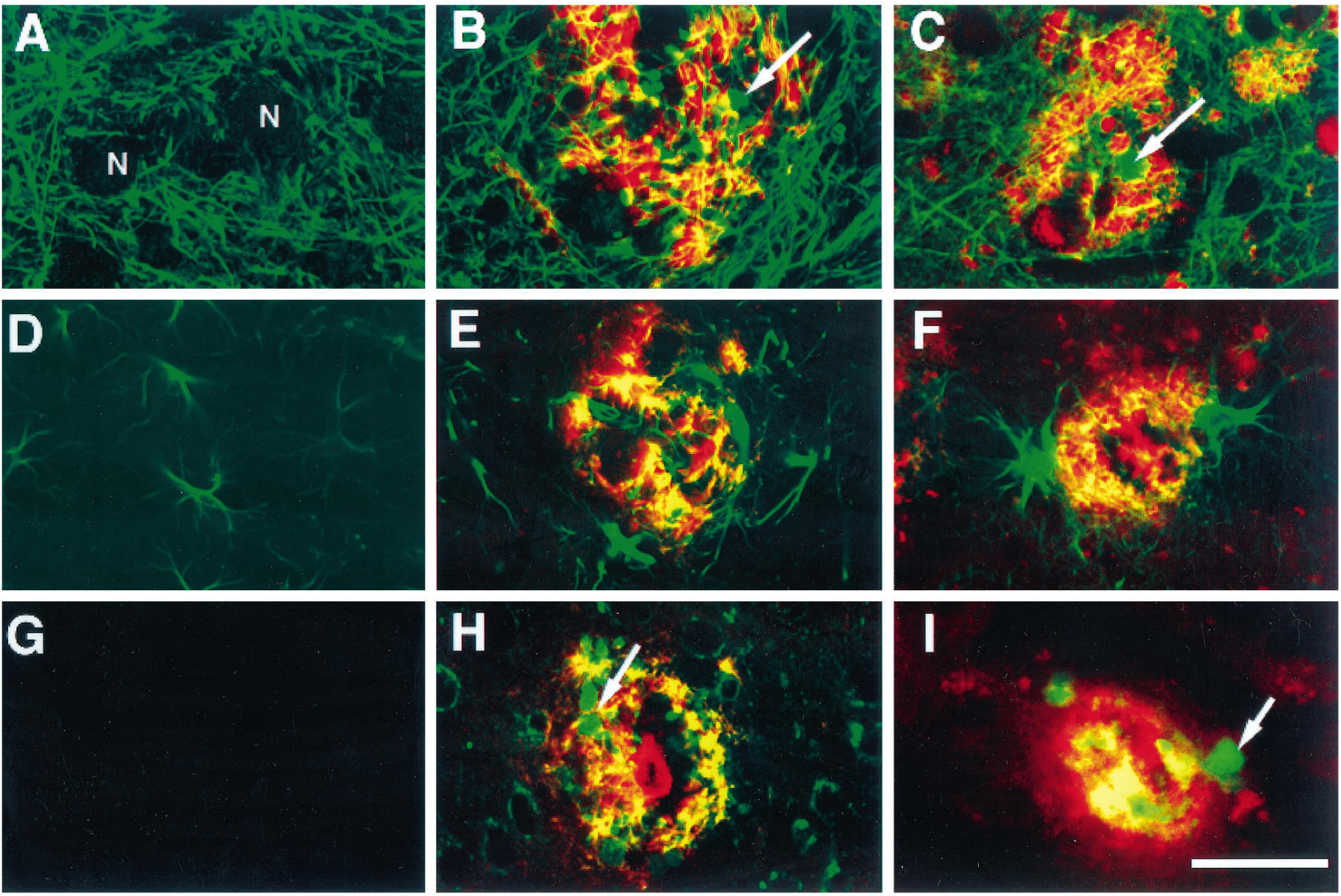

Figure 4. Comparison of the neuritic and glial components in the PDAPP tg model and AD. Sections were double-immunolabeled and imaged with the laser scanning confocal microscope. Images obtained in the Texas Red channel correspond to $\beta$-amyloid (3D6) and in the FITC channel (green) to phosphorylated neurofilament (SMI312) $(A-C)$, GFAP $(D-F)$, or hAPP (8E5) $(G-I)$. A, Non-tg control mice displayed a well organized and preserved neuritic structure. The neuronal cell bodies $(N)$ were not labeled with the anti-neurofilament antibody. PDAPP tg $(B)$ and AD $(C)$ cases displayed significant disruption of the neuritic structure and positive anti-SMI312 immunoreactivity in the dystrophic neurites (arrow) associated with the plaque. $D$, Non-tg control mice displayed occasional GFAP-immunoreactive astroglial cells. PDAPP tg $(E)$ and AD $(F)$ cases displayed hypertrophic GFAP-immunoreactive astroglial cells in the periphery of the plaque. $G$, Non-tg control mice were negative with the antibody specific for hAPP. PDAPP $\operatorname{tg}(H)$ and $\mathrm{AD}(I)$ cases displayed positive anti-hAPP immunoreactivity in the dystrophic neurites (arrow) associated with the plaque. Scale bar, $20 \mu \mathrm{m}$.

lular amyloid fibrils adjacent to the rough endoplasmic reticulum (RER) (Fig. $7 E$ ) and coated vesicles (Fig. $7 F, G)$, suggesting the possibility that neurons embedded in the plaque participate in amyloid synthesis. These subcellular organelles associated with intracellular amyloid formation in the PDAPP tg mice were similar to those described previously in amyloid-related cells (ARC) of the AD neuritic plaques (Roher et al., 1988; Frackowiak et al., 1992). However, whereas in AD the extracellular amyloid bundles contained several clear vesicles (Fig. $5 D, F$ ) that have been associated with pinocytic functions of the ARCs (Roher et al., 1988), in PDAPP tg mice these were only occasionally observed (Fig. 5B).

\section{Plaque-associated neuronal alterations}

In PDAPP tg mice, neuronal alterations were characterized by involvement of their processes in plaques (Figs. 3, 6) and by damage to their synaptic terminals (Fig. 8). The neuronal cell bodies in close proximity to the plaques formed neuritic processes that were associated with the amyloid core as well as with the dystrophic neurites (Fig. 6). Serial section analysis of electron micrographs and optical sections revealed that neuronal cell bod- ies and their processes could be identified in $>80 \%$ of the neuritic plaques (Figs. 1-3, 6). The neuronal origin of these cells was determined by the presence of the following: (1) immunoreactivity with antibodies against high and intermediate molecular weight phosphorylated neurofilaments (Fig. 3B); (2) dense-core vesicles $(85-250 \mathrm{~nm}$ in diameter) in the cell body and processes (Figs. $6 C$, $7 D, E)$; and (3) synapses between adjacent neuritic processes and the neuronal cell bodies (Fig. $8 A$ ) or between neurites embedded in the plaque and dystrophic neurites (Figs. $2 E, 8 D, E$ ). Furthermore, the nucleus of these cells usually presented moderate chromatin aggregation within the nuclear envelope and a prominent nucleolus (Figs. $1 C, 6 A$ ).

Neurons embedded in the plaque appeared to be actively involved in biosynthesis of proteins as evidenced by the presence of a prominent Golgi apparatus (Fig. $7 A$ ) and RER (Figs. 6C, 7A) in the perinuclear region. In addition, the neuritic processes embedded in the plaque contained abundant mitochondria, electrodense bodies surrounded by a membrane (suggesting a lysosomal origin), and dense-core vesicles (Figs. $6 C, 7 B-E$ ). The neurosecretory vesicles were occasionally distributed along the main neuritic process and were more abundant and enlarged in the distal end of 

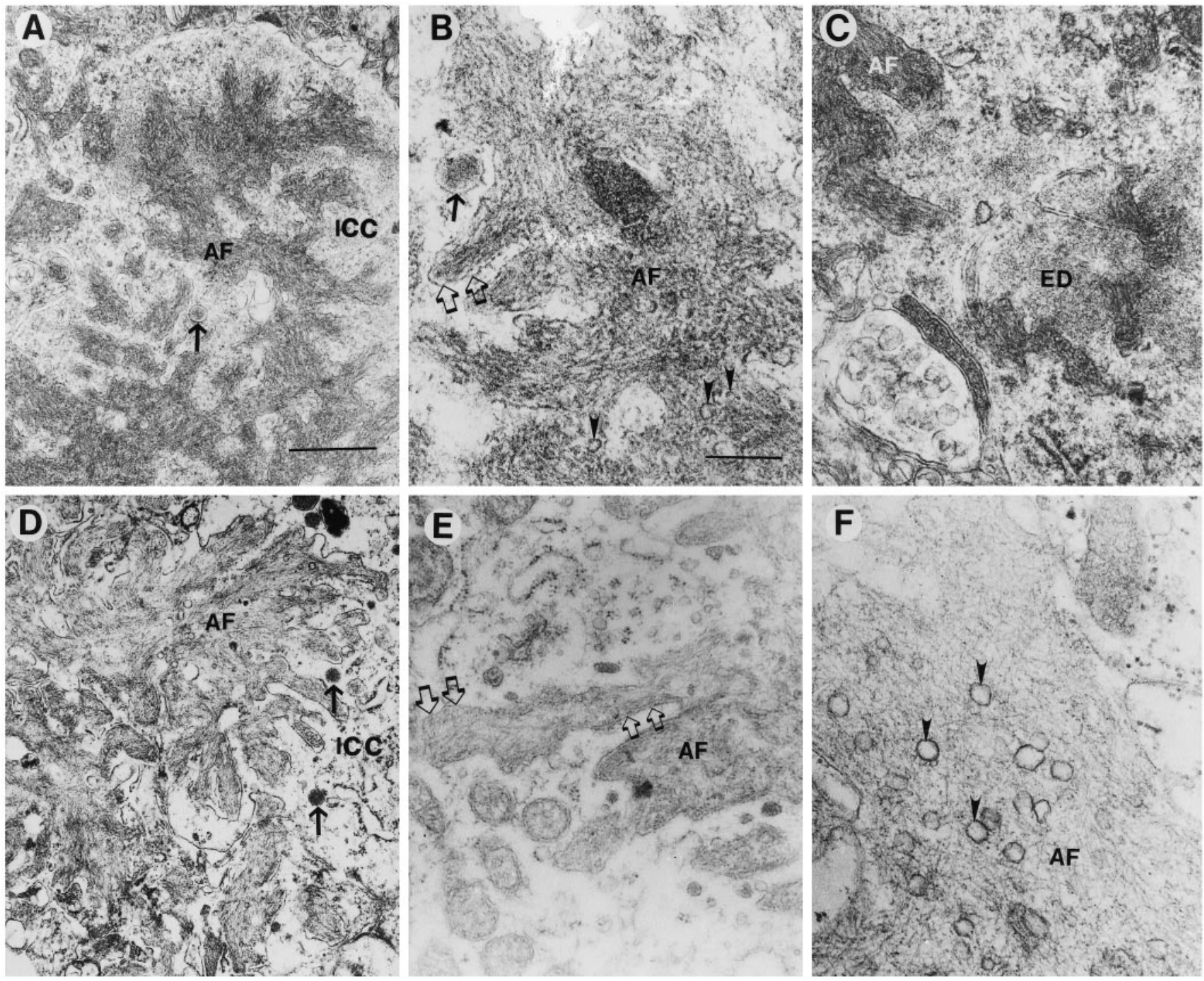

Figure 5. Comparison of the amyloid deposits in the PDAPP tg model and AD. Electron micrographs were obtained from the hippocampal region in the PDAPP tg mouse and from the frontal cortex in AD. Low-power $(A)$ and high-power $(B)$ view of amyloid fibrils $(A F)$ in the PDAPP tg mouse showing dense deposits surrounded by a membrane (open arrows) and the neuronal intracytoplasmic compartment (ICC) containing electrodense granular material and dense-core neurosecretory vesicles (arrow). Occasional poorly defined clear vesicles (arrowheads) were associated with the amyloid fibrils in PDAPP mouse plaques. $C$, In the PDAPP tg mouse, the cytoplasmic component of neurons close to the extracellular amyloid fibrils $(A F)$ showed the presence of amorphous electrodense material $(E D)$. Low-power $(D)$ and high-power $(E)$ view of the amyloid deposits in AD showed abundant dense fibrils $(A F)$ surrounded by a membrane (open arrows) and a cytoplasmic compartment (ICC) containing dense-core neurosecretory vesicles (arrows) and electrodense granular material. $F$, Clear vesicles were prominently associated with the amyloid fibrils $(A F)$ in $\mathrm{AD}$ plaques $($ arrowheads). Scale bars: $A$, $1 \mu \mathrm{m} ; B, 100 \mathrm{~nm}$.

the process adjacent to the amyloid deposits (Fig. $7 B-E$ ). In $\mathrm{AD}$, similar neuronal cells were observed associated with neuritic plaques (Fig. 2C); however, they were less prominent than in PDAPP tg mice.

Other neurodegenerative alterations observed in the PDAPP tg mice that were similar to AD (Masliah et al., 1991a, 1993b) included the damage to synaptic junctions. This was characterized by irregular enlargement of nerve terminals (Fig. 8C,F), fewer synaptic vesicles (Fig. $8 C, D$ ), and abnormal accumulation of multilaminar bodies, dense-core vesicles (Fig. $8 E, F$ ), and electrodense amorphous material (Fig. $8 B$ ). These synaptic alterations were more prominent inside the plaque than in the periplaque region.

\section{Dystrophic neurites in the plaques}

In addition to the neuritic alterations associated with amyloid formation described in the previous two sections, the neurites in the plaques of PDAPP tg mice also showed characteristic dystrophic changes. These dystrophic neurites contained abundant multivesicular, multilaminar dense bodies (Figs. $1 A, 2 E, 9 A-C$ ) as well as dense-core vesicles and small clear synaptic vesicles (Figs. $2 E, 8 C-E)$. Occasionally, synaptic contacts were observed between dystrophic neurites (Figs. 2E, 8E). The ultrastructural characteristics of the dystrophic neurites in the plaques of the PDAPP tg mice were essentially identical to those observed in type I neurites (Masliah et al., 1993b) in the plaques of AD cases (Fig. $2 C, F$ ), indicating that neurites in the plaques are probably 

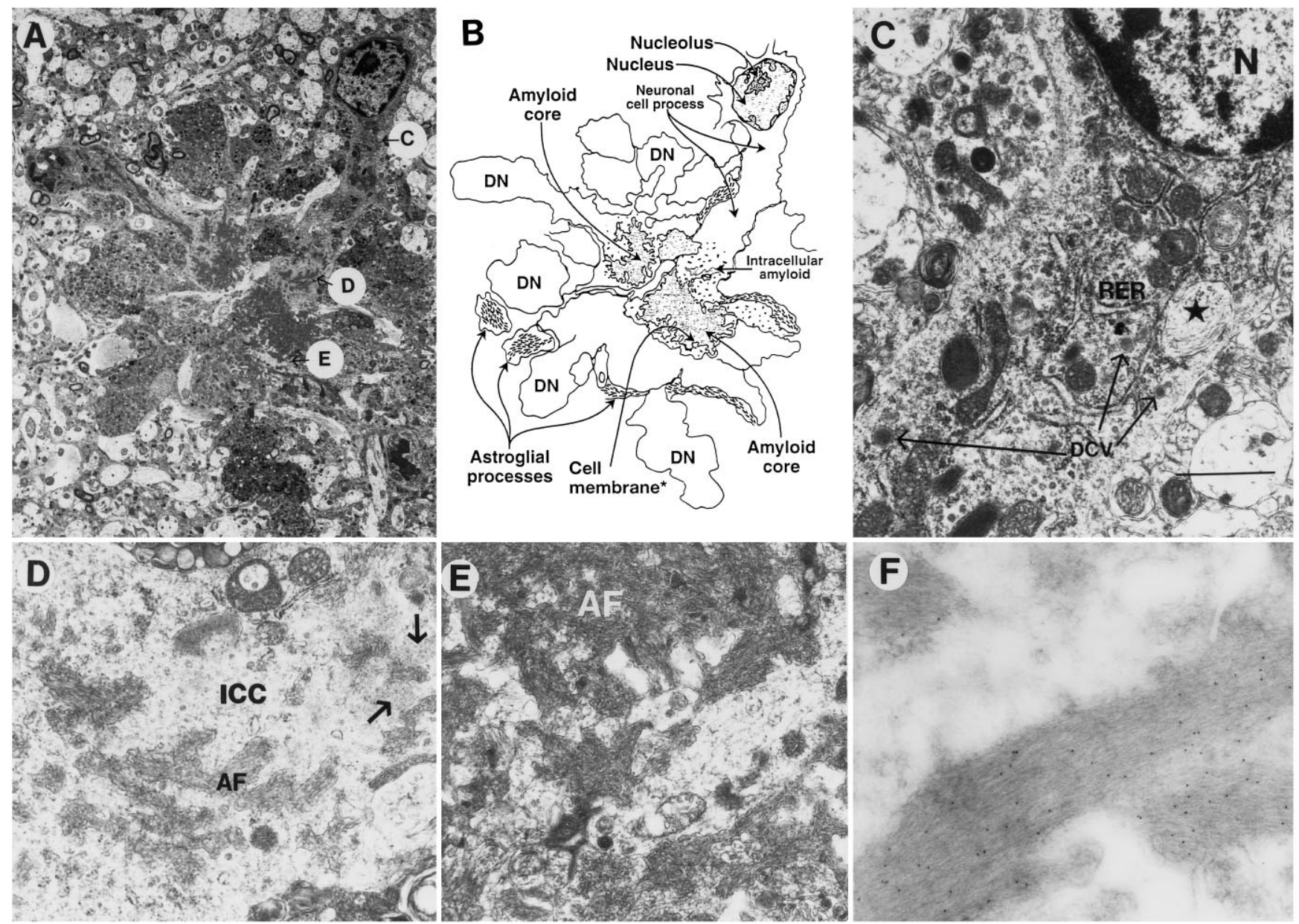

Figure 6. Subcellular neuronal alterations associated with the neuritic plaques in PDAPP tg mouse. Electron micrographs were taken from a lesion in the hippocampus. A, Low-power view of a neuritic plaque composed of a prominent neuronal element accompanied by extensive neuritic dystrophy, amyloid deposits, and astroglial cell reaction. The letters inside circles correspond to subsequent panels that identify various characteristics of the neuronal element in the plaque in greater detail. $B$, Diagrammatic representation of the neuritic plaque illustrated in $A$. $C$, Proximal to the nucleus (and distal to the amyloid core), the neuron displayed abundant RER, neurosecretory dense-core vesicles (long arrows), and peculiar elliptical bodies containing fibrilo-tubular material (*). Scale bar, $3 \mu \mathrm{m}$. $D$, Distal to the cell nucleus (and proximal to the amyloid core), the intracellular cytoplasmic compartments $(I C C)$ of the neuronal process displayed amyloid fibrils $(A F)$ and amorphous electrodense granular material (arrows) surrounded by a membrane-forming digitating processes $(E)$. The neuronal cytoplasm surrounding the extracellular amyloid fibrils $(A F)$ showed diffuse granular material and mitochondria. $F$, Immunogold labeling with a monoclonal antibody against $\beta$-amyloid (3D6) showed amyloid fibrils decorated with the $5 \mathrm{~nm}$ gold particles.

undergoing reactive and neurodegenerative changes (Masliah et al., 1993b). Consistent with previous studies (Masliah et al., 1993b), the type I dystrophic neurites in the PDAPP and AD cases were immunoreactive with antibodies against hAPP (8E5) (Fig. 4, $H$ and $I$, respectively).

In the PDAPP tg mice, some dystrophic neurites in the plaque contained a dense cumulus of cytoskeletal filaments that was surrounded by multilaminated bodies (Fig. 10A,B). These filaments, ranging in diameter between 8 and $10 \mathrm{~nm}$, were identical to neurofilaments. Consistent with these findings, doubleimmunolabeling studies confirmed that the dystrophic neurites in the plaques of the PDAPP and AD cases were immunoreactive with antibodies against phosphorylated middle and high molecular weight neurofilaments (Fig. 4, $B$ and $C$, respectively). They formed a reticular matrix and were observed in both myelinated (Fig. 10 $A, B$ ) and nonmyelinated (Fig. 9A) axons. Although clearly different from PHF of the type II dystrophic neurites in the plaques of AD cases (Masliah et al., 1993b), they were similar to neurofilament aggregates occasionally observed in the type I neurites of the $\mathrm{AD}$ plaques (Fig. 10C,D). No classical AD-type PHF was observed in the dystrophic neurites of PDAPP tg mice (Fig. $10 E, F)$. In addition to the neurofilamentous alterations observed in the neuritic plaques of PDAPP tg mice, detailed ultrastructural analysis revealed the presence of crystalline polygonal structures that were formed by symmetrical tubular elements (Fig. 9D-F).

\section{Other cellular alterations not associated with plaques}

In addition to neuritic plaque formation, neurodegenerative changes in neocortical and hippocampal cells of the PDAPP tg mice included nuclear chromatin segmentation, formation of dense intranuclear and intracytoplasmic bodies, and intracellular vacuolization of the membranes (Fig. 11). Some cells contained RER and neurosecretory vesicles, suggesting a neuronal origin. However, in cells with extensive vacuolization it was not possible to identify ultrastructural markers indicative of cellular origin. These alterations were not observed in control non-tg littermates. Neurons of PDAPP tg mice that were not associated with plaques showed no neurofibrillary tangles (NFT) or evidence of intraneuronal PHF formation. 

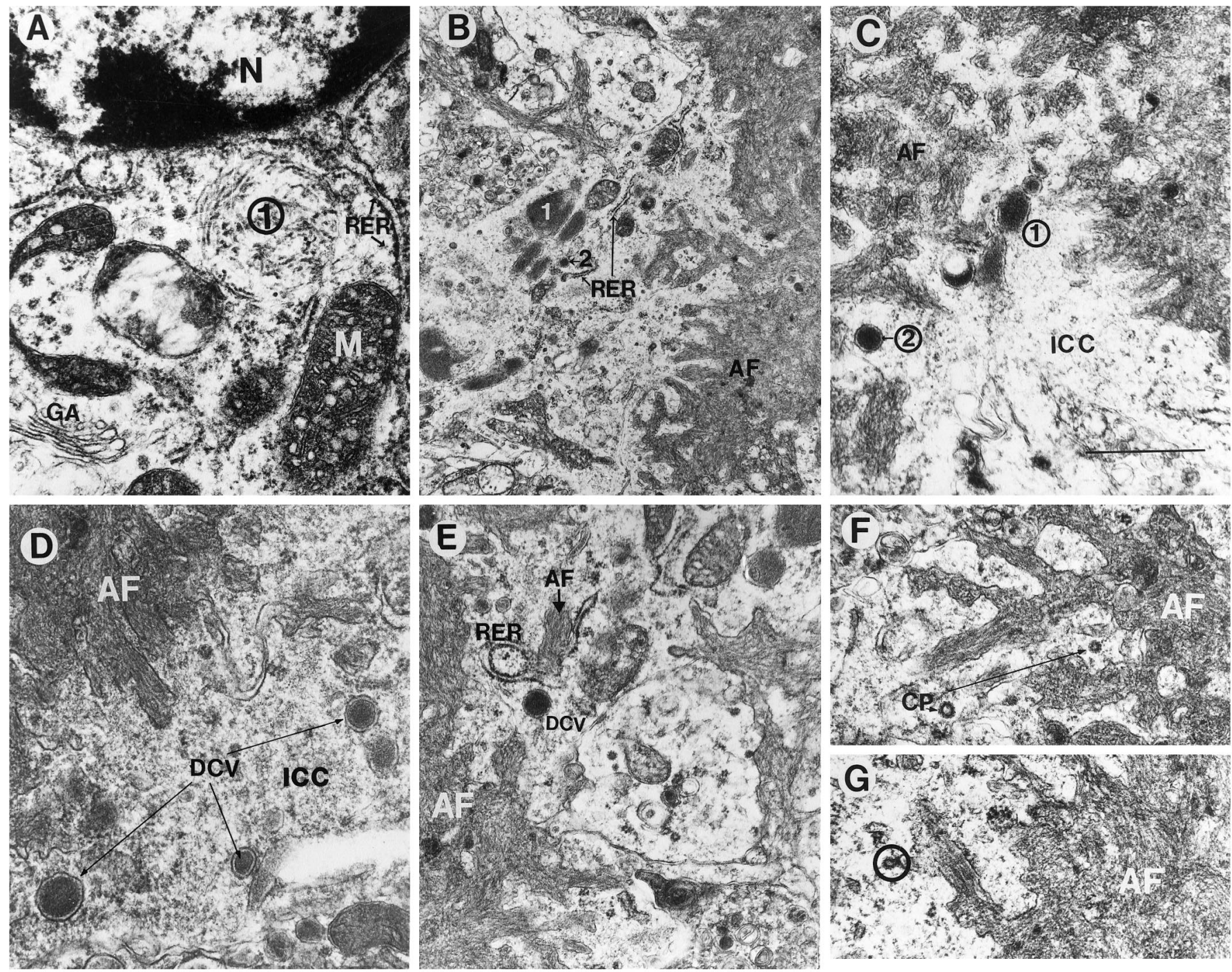

Figure 7. Additional neuronal subcellular characteristics associated with amyloid formation in the PDAPP tg mouse. Electron micrographs were obtained from the hippocampus and are derived from the neuritic plaque presented at the bottom of Figure $3 D$. $A$, Proximal to the nucleus $(N)$ (and distal to the amyloid core), the neuron displayed, in addition to RER and elliptical inclusion bodies (1), a prominent Golgi apparatus $(G A)$ and mitochondria $(M)$. B, Distal to the cell nucleus (and proximal to the amyloid core), the cytoplasm of the neuronal process displayed the presence of compact electrodense organelles surrounded by a membrane (1) adjacent to RER, mitochondria, and neurosecretory vesicles (2). $C, D$, Dense-core neurosecretory vesicles $(1,2)$ were abundant in the intracytoplasmic compartment $(I C C)$ of the neuron adjacent to the extracellular amyloid fibrils $(A F)$. $E$, Intracellular amyloid fibrils $(A F$, black letterhead) adjacent to RER were present in the cytoplasmic compartment of the neurons near the extracellular amyloid fibrils $(A F$, white letterhead $)$. Dense-core neurosecretory vesicles $(D C V)$ were also present. $F, G$, Coated pits $(C P)$ in the cytoplasmic compartment of the neurons were closely associated with the plasma membrane (circle) surrounding extracellular amyloid deposits $(A F)$. Scale bar, $400 \mathrm{~nm}$.

\section{Glial cell alterations}

Abundant glial cells were observed around the neuritic plaques (Figs. $1 C, 3 D, E, 12$ ) as well as scattered in the neuropil of the neocortex and hippocampus of the PDAPP tg mice. The great majority of them contained intermediate filaments, consistent with an astroglial origin (Fig. 12). In both the PDAPP and the AD cases, these glial elements in the plaque strongly immunoreacted with antibodies against the astroglial marker (GFAP) (Fig. 4, $E$ and $F$, respectively). Microglial cells were observed associated with neuritic plaques containing dense amyloid cores and in which the dystrophic neurites exhibited extensive degeneration characterized by the presence of abundant electrodense material. Compared with $\mathrm{AD}$, neuritic plaques in PDAPP tg mice showed a more prominent astroglial reaction and a less abundant microglial component (not shown) (Terry et al., 1964; Terry and Wisniewski, 1970; Frackowiak et al., 1992).

\section{DISCUSSION}

\section{Neurodegeneration in PDAPP tg mice}

The present study showed that PDAPP tg mice displayed subcellular neurodegenerative alterations strikingly similar to those observed in AD (Table 1). These include characteristic dystrophic neurites with electrodense multilaminar bodies, disruption of synaptic junctions, and intracellular amyloid and reactive gliosis. Furthermore, plaques in PDAPP tg mice displayed extracellular amyloid fibrils associated with cellular processes containing dense-core vesicles, coated vesicles, RER, and membranous recesses in the neuritic plaques (Table 1). 

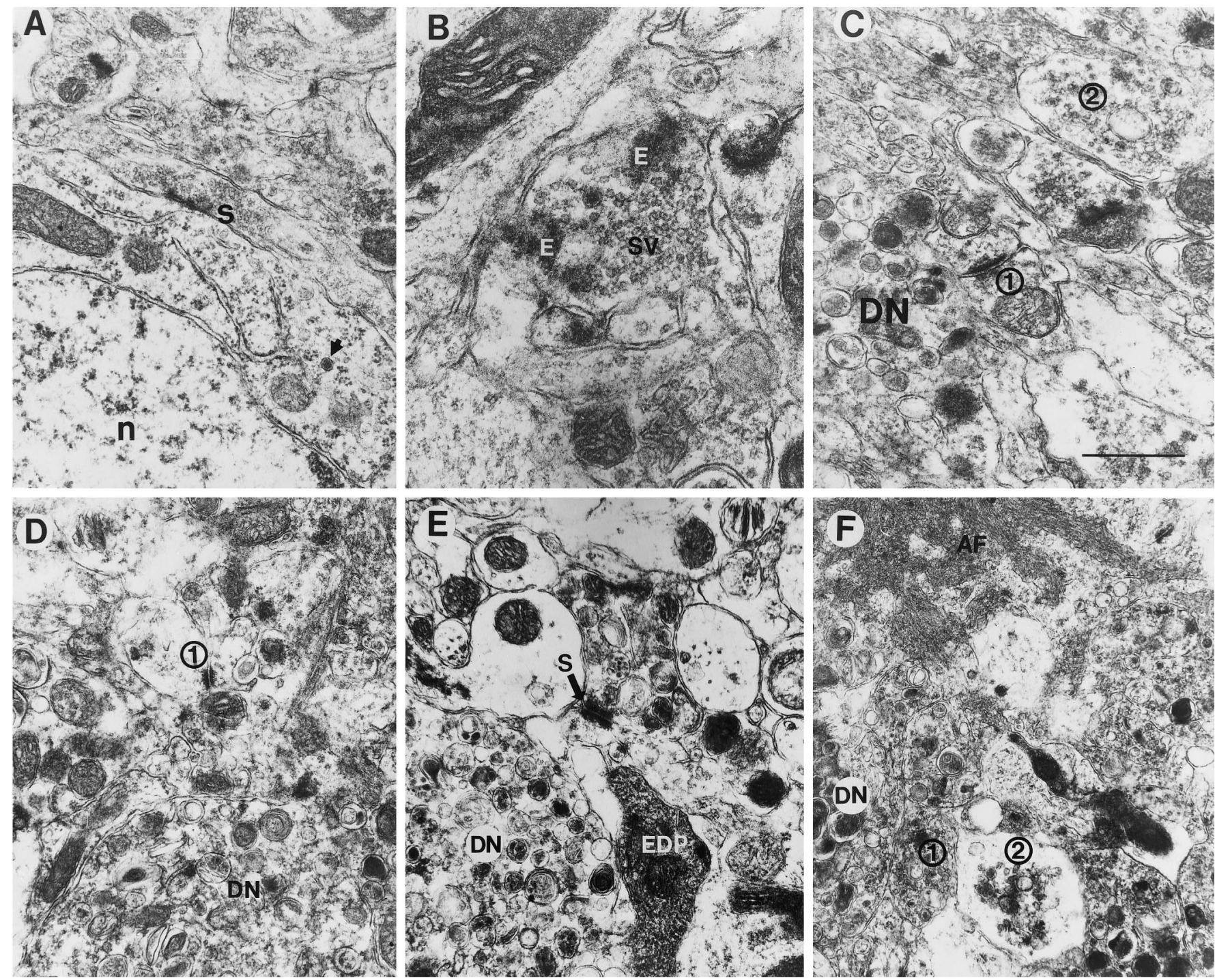

Figure 8. Synaptic alterations in PDAPP tg mice. Electron micrographs were obtained from the hippocampus. $A$, Neuronal cells associated with the plaques showed synaptic terminals $(S)$ associated with the perikaryon ( $n$, nucleus; arrow, neurosecretory vesicle). $B$, Presynaptic terminals in the periplaque region displayed amorphous electrodense material $(E)$ in addition to synaptic vesicles $(S V)$. $C, D$, Some synaptic terminals in the periplaque region showed decreased numbers of synaptic vesicles (1), whereas others were distended and contained abundant vesicles (2) (DN, dystrophic neurites). $E$, Axonal terminals in the midst of the plaque were distended and displayed accumulations of multilaminar, multivesicular, and electrodense bodies. Dystrophic neurites $(D N)$ made occasional synaptic contacts $(S)$ with neighboring neuritic processes. Other neuritic elements in the plaque were electrodense $(E D P) . F$, Adjacent to the extracellular amyloid fibrils $(A F)$, the axonal terminals were distended and contained abundant dense vesicles $(1)$ or clear vesicles (2). A dystrophic neurite $(D N)$ was also present. Scale bar, $1.5 \mu \mathrm{m}$.

Whereas neuritic plaques in $\mathrm{AD}$ contained spherical (type I) and fusiform (type II) neurites (Masliah et al., 1993b), in PDAPP tg mice the neuritic component was mainly of the spherical type (type I). This is consistent with the finding that, to date, no PHF has been found in neuronal cell bodies or dystrophic neurites in the PDAPP tg mice. In fact, the plaques occasionally found in cognitively intact aged humans and macaques (Martin et al., 1994) display the presence of type I (but not type II) dystrophic neurites, amyloid fibrils, and astrocytic reaction, as is the case with the PDAPP tg mice. However, similar to AD, the plaques in the PDAPP tg mice appear to be more abundant and show more widespread neuritic dystrophy than the ones observed in aged humans and macaques. Furthermore, similar to ultrastructural findings in AD (Wisniewski and Terry, 1970, 1973; Wisniewski et al., 1970; Masliah et al., 1993b), the neuritic component of plaques in the PDAPP tg mice contained both dystrophic (i.e., mitochondria, lysosomes, and neurofilaments) and regenerative (i.e., clear and dense-core vesicles, mitochondria, ER, and lysosomes) alterations. Previous studies showed that similar ultrastructural alterations occurred in neurites of vitamin E-deficient rats (Lampert, 1967; Southam et al., 1991) and in grafts of peripheral nerves in the CNS (Campbell et al., 1992). Furthermore, consistent with previous studies in AD (Terry et al., 1964; Gonatas et al., 1967; Wisniewski et al., 1981; Masliah et al., 1991b, 1993b), several of the plaque neurites in PDAPP tg mice contained synaptic vesicles and formed synaptic contacts supporting an axonal role and origin of neuritic dystrophy. The neuritic plaque components associated with dense amyloid deposits were of the degenerative type, because they contained abundant electrodense deposits and multilaminar bodies consistent with alter- 

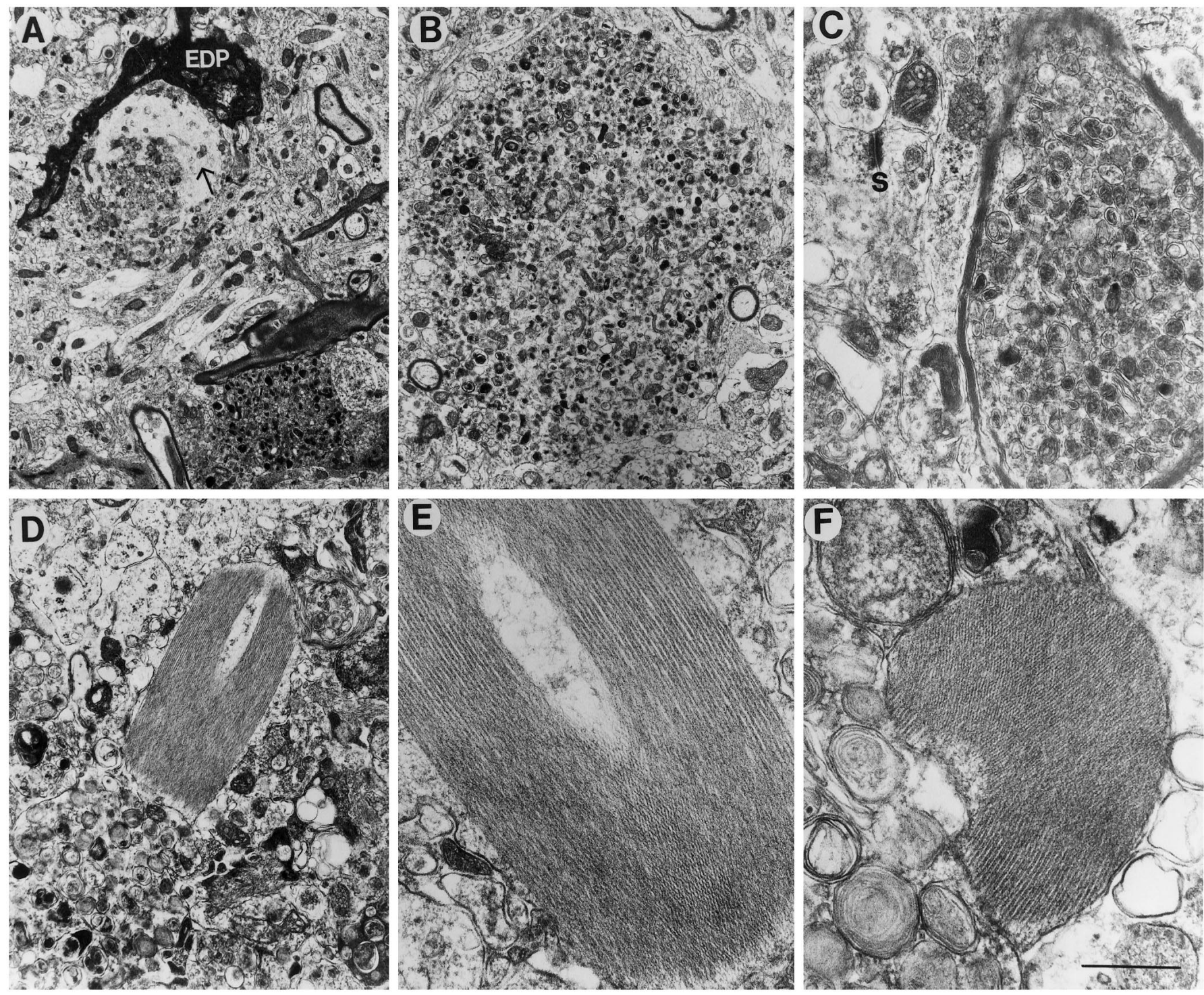

Figure 9. Neuritic alterations in PDAPP tg mice. Electron micrographs were obtained from the hippocampus. In PDAPP tg mice, the dystrophic unmyelinated $(A, B)$ and myelinated neurites $(C)$ contained abundant electrodense laminar and multivesicular bodies. Some neurites contained fine filaments $(10 \mathrm{~nm}$; arrow $)$ and were surrounded by electrodense processes $(E D P)$. Other neurites contained characteristic crystals displaying an array of symmetrically organized tubules $(D-F)$. Scale bar, $2 \mu \mathrm{m}$.

ations observed in other animal models of neurodegeneration (Lampert, 1967).

In addition to neuritic plaque formation, neurodegenerative changes in neocortical and hippocampal cells of the PDAPP tg mice included nuclear chromatin segmentation, formation of dense intranuclear and intracytoplasmic bodies, and vacuolization. These alterations are similar to apoptotic changes observed in experimental models after treatment with excitotoxins (Pollard et al., 1994; Portera-Cailliau et al., 1995) or adrenalectomy (Sloviter et al., 1993). In contrast to these experimental animal models, previous ultrastructural studies have not described extensive apoptotic changes in cells in AD (Terry et al., 1964; Terry and Wisniewski, 1970). However, recent studies utilizing the in situ labeling technique have suggested that both neurons and glial cells undergo apoptosis in AD (Forloni et al., 1993; Su et al., 1994; Dragunow et al., 1995; Lassman et al., 1995; Smale et al., 1995), as well as in another $\mathrm{A} \beta$ tg animal model (LaFerla et al., 1995).

\section{Cytoskeletal alterations in PDAPP tg mice}

Consistent with findings in AD, PDAPP tg mice also showed cytoskeletal alterations characterized by abnormal deposits of neurofilamentous material in neuronal cell bodies, as well as in neuritic plaques. Similar alterations have been described in dystrophic neurites in AD (Wisniewski and Terry, 1973; Gheuens et al., 1991), as well as in rodents and humans treated with antimitotic agents (Wisniewski and Terry, 1967; Schochet et al., 1968; Shelansky, 1969; Nakagawa et al., 1987) and in rabbits treated with aluminum (Terry and Pena, 1965). In addition to the neurofilamentous deposits, PDAPP tg mice displayed the formation of crystals formed by symmetrical tubular elements arranged in an angular manner. These crystals had some ultrastructural similarities to Hirano bodies; however, additional electron microscopic and immunocytochemical studies will be necessary to confirm the origin of these struc- 

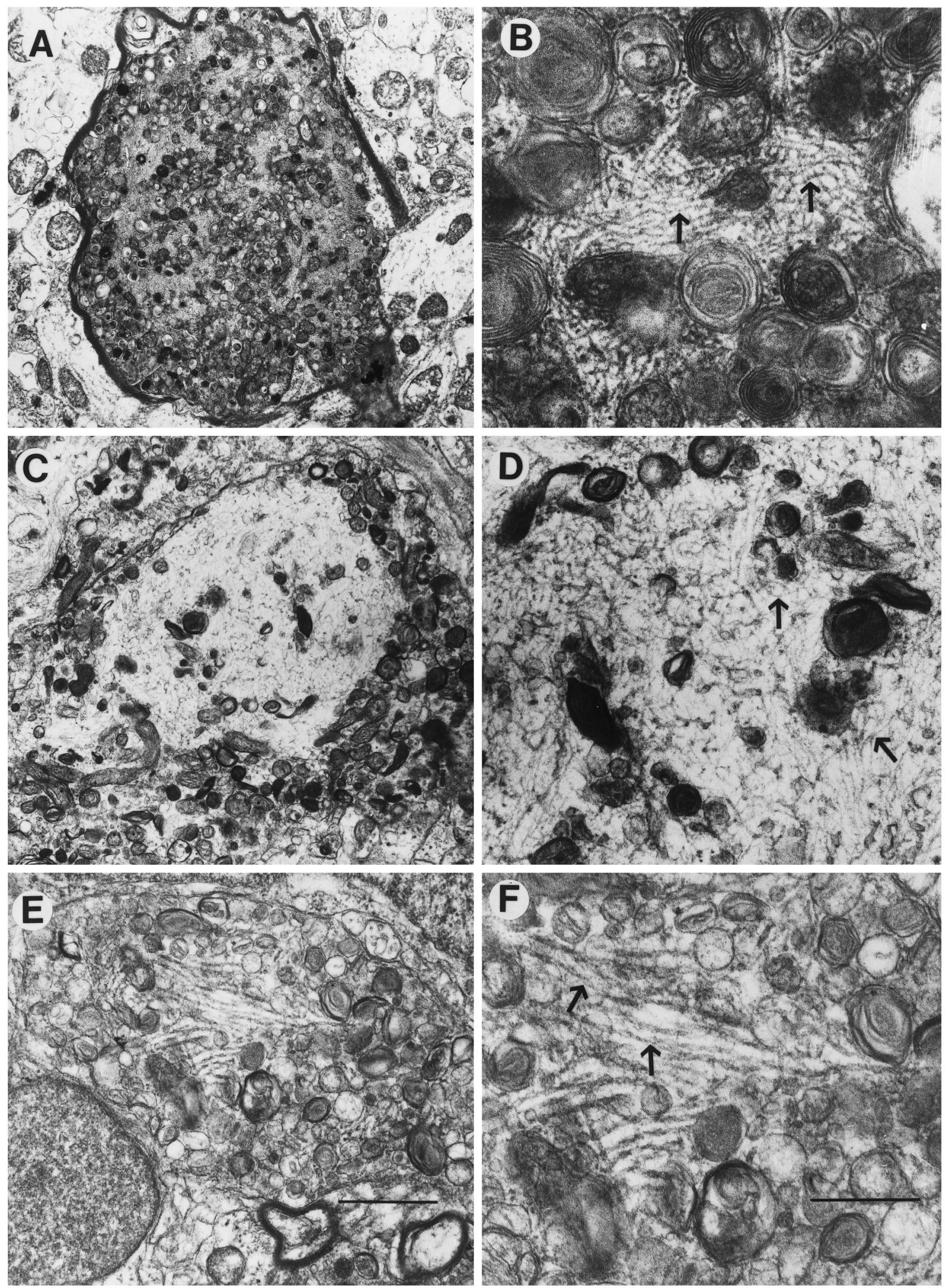

Figure 10. Comparison of cytoskeletal alterations between the PDAPP tg mouse and AD. Low-power $(A)$ and high-power $(B)$ views of a myelinated dystrophic neurite in the PDAPP tg containing abundant laminated bodies and filamentous material $(10 \mathrm{~nm}$ in diameter; arrows). Low-power $(C)$ and high-power $(D)$ views of a dystrophic neurite in $\mathrm{AD}$ containing multilaminar bodies and neurofilamentous material similar to the one observed in the PDAPP mouse (arrows). Low-power $(E)$ and high-power $(F)$ views of a dystrophic neurite in AD containing classical paired helical filaments (arrows). Scale bars: $E, 5 \mu \mathrm{m} ; F, 200 \mathrm{~nm}$. 

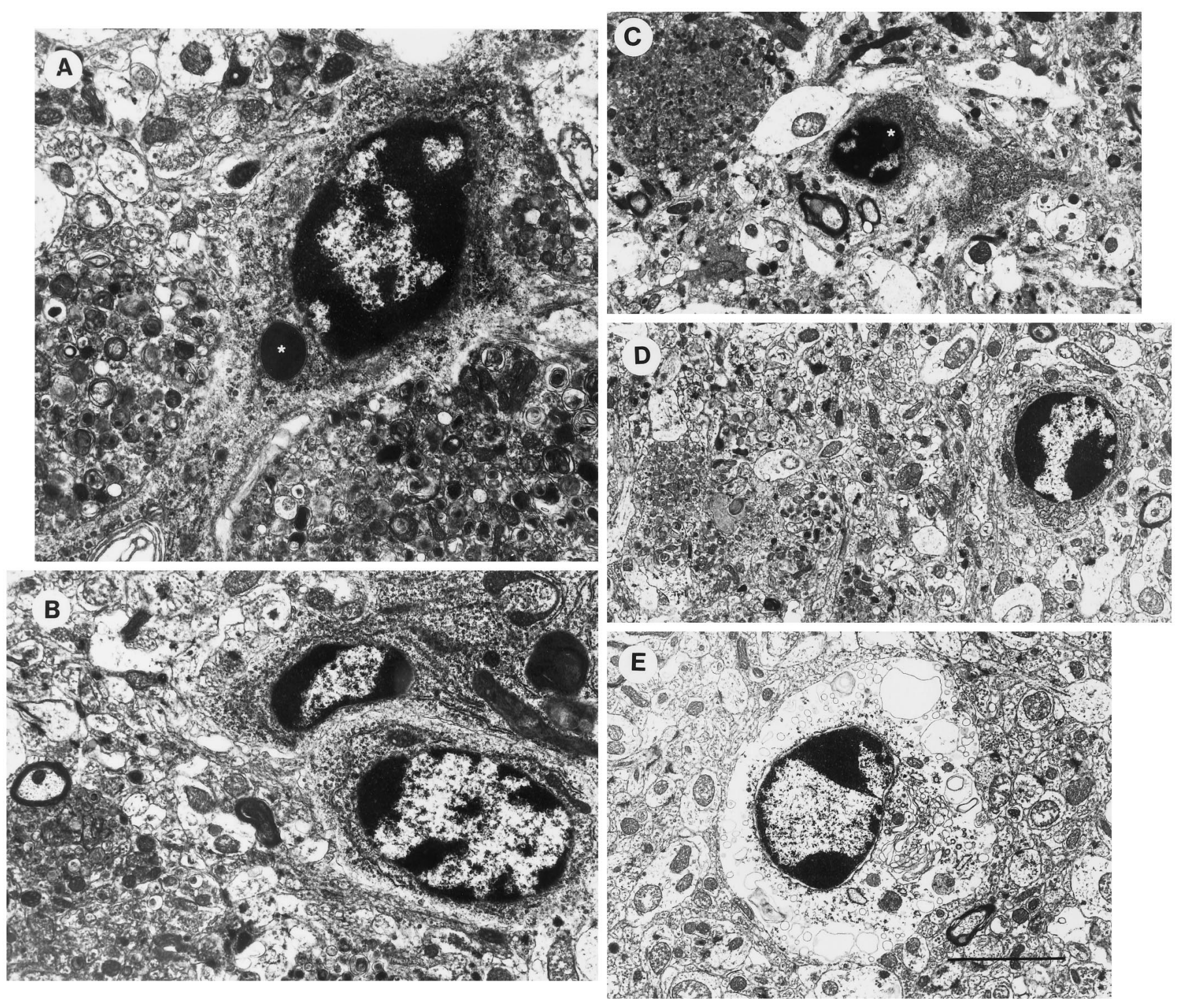

Figure 11. Apoptotic-like changes in neocortical cells of PDAPP tg mice. Electron micrographs were obtained from layer 5 of the frontal cortex. $A-D$, Neuronal nuclei contained chromatin segmentation and condensation. Some cells displayed dense intracytoplasmic or intranuclear inclusions surrounded by a membrane $(*)$. These cells also contained RER and neurosecretory vesicles. E, Other cells displayed, in addition to the chromatin segmentation, cytoplasmic distention and vacuolization. Scale bar, $10 \mu \mathrm{m}$.

tures. Hirano bodies are crystalloid structures that preferentially occur in the CA1 area of the hippocampus in AD, amyotrophic lateral sclerosis, Parkinsonism/dementia complex, and other disorders (Hirano, 1994). Because Hirano bodies contain actin, neurofilaments, and tau immunoreactivity, they are considered part of the spectrum of cytoskeletal alterations that occur in AD (Hirano, 1994). These crystals have also been described in rodents treated with colchicine and in aged primates (Hirano, 1994). Taken together, these findings suggest that overexpression of mutated hAPP or $\mathrm{A} \beta$ in $\mathrm{tg}$ mice is associated with neuritic cytoskeletal alterations. These changes could be secondary to the neurodegenerative process associated with a limited sprouting capacity in partially denervated neurons, consistent with the observation that sprouting neurites expressing GAP-43 and APP also display neurofilament immunoreactivity (Cras et al., 1991; Gheuens et al., 1991; Masliah et al., 1991b, 1993a).

\section{Amyloid fibril similarities between PDAPP tg mice and $\mathrm{AD}$}

Another prominent feature in the PDAPP tg mice, occasionally observed in $\mathrm{AD}$, was the presence of neuronal elements in close association with the plaques, suggesting the possibility that extracellular amyloid was derived from these structures. Neuronal processes embedded in plaques contained discrete amyloid bundles associated with their RER, as well as large membranous electrodense bodies, coated vesicles, and dense-core neurosecretory vesicles that were also closely associated with amyloid deposits. Moreover, these subcellular neuronal alterations were more prominent and abundant around the amyloid core. Similar sub- 

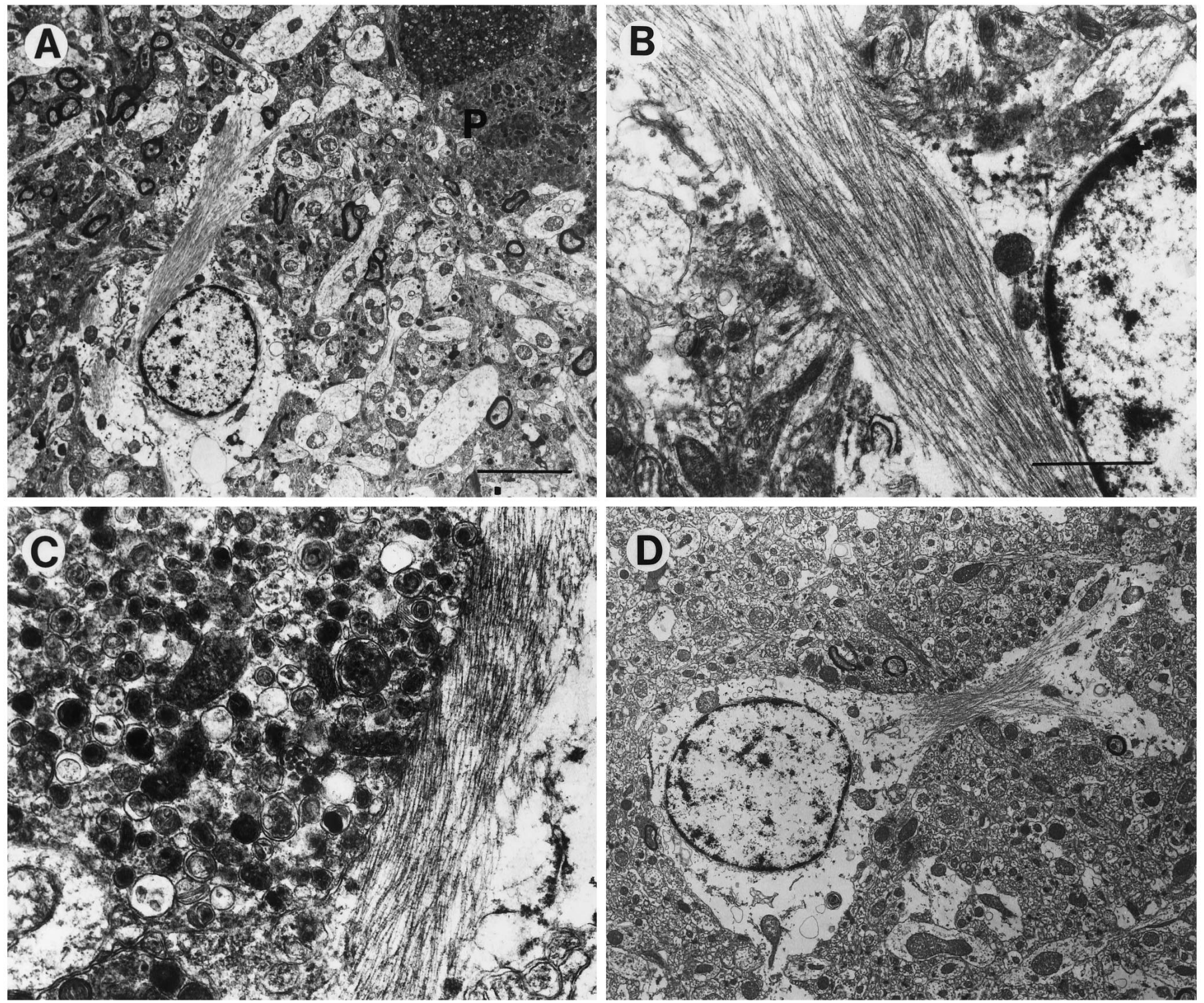

Figure 12. Glial cell alterations in PDAPP tg mice. Electron micrographs were obtained from the frontal cortex. $A$, Prominent astrocytic cells were observed associated with the neuritic plaques $(P)$. These cells displayed some cytoplasmic swelling and contained abundant intermediate filaments. $B, C$, Higher-power view of the astrocytic processes in the plaque. $D$, View of an enlarged astrocyte distant from the plaque. Scale bars: $A, 10 \mu \mathrm{m} ; B, 2 \mu \mathrm{m}$.

cellular findings have been reported in amyloid-producing cells in AD (Roher et al., 1988; Wisniewski et al., 1991). The role of the dense-core vesicles in this process is uncertain, but previous studies have shown that these vesicles are abundant in dystrophic neurites of AD (Weiler et al., 1990; Munoz, 1991) and are rich in chromogranin, indicating that these cellular processes are of axonal origin and that neurosecretory granules could be involved in the process of amyloid formation.

The precise sequence of events that lead to plaque formation remains to be resolved. Nevertheless, the findings reported here, together with observations from other animal models (Cork et al., 1990) as well as AD (Masliah et al., 1993b; Heinonen et al., 1995; Masliah, 1995), suggest that plaque formation initiates with local synaptic alterations induced by possible abnormalities in APP processing and $\mathrm{A} \beta$ formation. The overproduction of the amyloidogenic $\mathrm{A} \beta$ (1-42) peptide that occurs as a result of the APP717 mutation in the PDAPP tg mouse is likely also to be critical to the rapid development of plaques seen in this animal model of $\mathrm{AD}$ (Suzuki et al., 1994). These events might then be followed by dystrophic neurite formation and extracellular amyloid deposition. These dystrophic neurites might represent regenerative and sprouting terminals and may eventually degenerate to become electrodense processes associated with plaques containing abundant dense amyloid. Supporting this contention, recent studies in PDAPP tg mice of various ages have shown that synaptic and neuritic alterations in the limbic system occur early and are closely followed by microdeposits of $\beta$-amyloid (Games et al., 1995a,b). Neuronal alterations and amyloid deposition in the neocortex appear at a later time point. Further studies in PDAPP tg mice of various ages are underway to clarify the progression of the neurodegenerative changes and plaque formation. An alternative explanation could be that neuronal uptake of extracellular amyloid fibrils, followed by disruption of the subcellular neuronal organelles triggers the cascade of events. However, this seems to 


\begin{tabular}{lll}
\hline $\begin{array}{l}\text { Table 1. Ultrastructural similarities and differences between AD and } \\
\text { PDAPP tg plaques }\end{array}$ & \\
& $\begin{array}{l}\text { Alzheimer's } \\
\text { disease }\end{array}$ & PDAPP tg \\
\hline Amyloid fibrils & & \\
Size & $9-11 \mathrm{~nm}$ & $9-11 \mathrm{~nm}$ \\
Electron density & Moderate & High \\
Pinocytic vesicles & Abundant & Occasional \\
Dystrophic neurites & & \\
Type I & Abundant & Abundant \\
Dense laminar bodies & Yes & Yes \\
Synaptic vesicles and contacts & Yes & Yes \\
Neurofilament accumulation & & \\
Type II & Yes & None? \\
Paired helical filaments & & \\
Cells associated with amyloid formation & Abundant & Occasional \\
Microglia & Occasional & Abundant \\
Neurons & Abundant & Abundant \\
Neurosecretory granules & Abundant & Abundant \\
Rough endoplasmic reticulum & Yes & Yes \\
Coated pits & & \\
\hline
\end{tabular}

be a less likely possibility because the ultrastructural characteristics of the cellular processes embedded in the plaque were different from the subcellular alterations previously identified in cells phagocytizing amyloid (Wisniewski et al., 1991; Frackowiak et al., 1992). It has been shown both in vitro and in vivo that cells which phagocytize amyloid contain nondegraded fibrils within phagosomes, whereas in cells which produce amyloid, fibrils appear first in altered RER deep infoldings of cell membranes (Wisniewski et al., 1991; Frackowiak et al., 1992). The neuronal processes embedded in the amyloid core of PDAPP tg mice contained abundant RER, neurosecretory vesicles, electrodense granular material, and coated vesicles, suggesting active synthesis and secretion of amyloidogenic elements rather than phagocytosis. These subcellular alterations in PDAPP tg mice imply that neurons play an important role in plaque formation and are not simply trapped in the midst of the lesions.

It has been postulated that microglial cells play an important role in amyloid formation in the AD plaque (Terry et al., 1964; Wisniewski and Terry, 1970; Roher et al., 1988; Wisniewski et al., 1989, 1991; Masliah et al., 1991c; Frackowiak et al., 1992). Although microglial cells were observed in the plaques of PDAPP tg mice, they were not as prominent as those seen in AD. These differences might be related to differences in the stage and duration of the lesions in humans versus tg mice. Furthermore, it is possible that the currently ongoing analysis of aged PDAPP tg mice will reveal more prominent astroglial alterations. Interestingly, astroglial reaction around plaques was of similar prominence in PDAPP tg mice and AD cases.

In conclusion, this study shows that PDAPP tg mice share several critical subcellular alterations with $\mathrm{AD}$ that make them a valuable model in which to study mechanisms of neurodegeneration and plaque formation. Furthermore, marked neuronal overexpression of a mutant hAPP $(\mathrm{hAPP} 717 \mathrm{~V} \rightarrow \mathrm{F})$ can result in the accumulation of excess $\mathrm{A} \beta$ protein, and this accumulation may contribute to neurodegeneration and plaque formation seen in the PDAPP tg mice.

\section{REFERENCES}

Bonhomme V, Hans P, Collette J, Moonen G (1993) Neuron-specific enolase as a marker of in vitro neuronal damage. II. Investigation of the astrocyte protective effect against kainate-induced neurotoxicity. J Neurosurg Anesthesiol 5:117-120.

Campbell G, Lieberman AR, Anderson PN, Turmaine M (1992) Regeneration of adult rat CNS axons into peripheral nerve autografts: ultrastructural studies of the early stages of axonal sprouting and regenerative axonal growth. J Neurocytol 21:755-787.

Chartier-Harlin M-C, Crawford F, Houlden H, Warren A, Hughes D, Fidani L, Goate A, Rossor M, Roques P, Hardy J, Mullan M (1991) Early-onset Alzheimer's disease caused by mutations at codon 717 of the $\beta$-amyloid precursor protein gene. Nature 353:844-846.

Clark RF, Goate AM (1993) Molecular genetics of Alzheimer's disease. Arch Neurol 50:1164-1172.

Cork LC, Masters C, Beyreuther K, Price DL (1990) Development of senile plaques: relationships of neuronal abnormalities and amyloid deposits. Am J Pathol 137:1383-1392.

Cras P, Kawai M, Lowery D, Gonzalez-DeWhitt P, Greenberg B, Perry G (1991) Senile plaque neurites in Alzheimer's disease accumulate amyloid precursor protein. Proc Natl Acad Sci USA 88:7552-7556.

Deftos LJ, Burton DW, Brandt DW (1993) Parathyroid hormone-like protein is a secretory product of atrial myocytes. J Clin Invest 92:727-735.

Dickson DW, Farlo J, Davies P, Crystal H, Fuld P, Yen SC (1988) Alzheimer's disease: a double immunohistochemical study of senile plaques. Am J Pathol 132:86-101.

Dragunow M, Faull RL, Lawlor P, Beilharz EJ, Singleton K, Walker EB, Mee E (1995) In situ evidence for DNA fragmentation in Huntington's disease striatum and Alzheimer's disease temporal lobes. NeuroReport 6:1053-1057.

Forloni G, Chiesa R, Smiroldo S, Verga L, Salmona M, Tagliavini F, Angeretti N (1993) Apoptosis mediated neurotoxicity induced by chronic application of $\beta$ amyloid fragment 25-35. NeuroReport 4:523-526.

Frackowiak J, Wisniewski HM, Wegiel J, Merz GS, Iqbal K, Wang KC (1992) Ultrastructure of the microglia that phagocytose amyloid and the microglia that produce $\beta$-amyloid fibrils. Acta Neuropathol 84:225-233.

Games D, Adams D, Alessandrini R, Barbour R, Berthelette P, Blackwell C, Carr T, Clemes J, Donaldson T, Gillespie F, Guido T, Hagopian S, Johnson-Wood K, Khan K, Lee M, Leibowitz P, Lieberburg I, Little S, Masliah E, McConlogue L, Montoya-Zavala M, Mucke L, Paganini L, Penniman E, Power M, Schenk D, Seubert P, Snyder B, Soriano F, Tan H, Vitale J, Wadsworth S, Wolozin B, Zhao J (1995a) Alzheimer-type neuropathology in transgenic mice overexpressing V717F $\beta$-amyloid precursor protein. Nature 373:523-527.

Games D, Carr T, Guido T, Khan K, Soriano F, Tan H, McConlogue L, Lieberburg I, Schenk D, Masliah E (1995b) Progression of Alzheimertype neuropathology in PDAPP $717 \mathrm{~V} \rightarrow \mathrm{F}$ transgenic mice. Soc Neurosci Abstr 21:258.

Gheuens J, Cras P, Perry G, Boons J, Ceuterick-de Groote C, Lubke U, Mercken M, Tabaton M, Ganbetti PL, Vandermeeren M (1991) Demonstration of a novel neurofilament associated antigen with the neurofibrillary pathology of Alzheimer and related diseases. Brain Res 558:43-52.

Goate A, Chartier-Harlin M-C, Mullan M, Brown J, Crawford F, Fidani L, Guiffra L, Haynes A, Irving N, James L, Mant R, Newton P, Rooke K, Roques P, Talbot C, Williamson R, Rossor M, Owen M, Hardy J (1991) Segregation of a missense mutation in the amyloid precursor protein gene with familial Alzheimer's disease. Nature 349:704.

Golde TE, Estus S, Younkin LH, Selkoe DJ, Younkin SG (1992) Processing of the amyloid protein precursor to potentially amyloidogenic derivatives. Science 255:728-730.

Gonatas NK, Anderson WW, Evangelista I (1967) The contribution of altered synapses in the senile plaque: an electron microscopic study in Alzheimer's disease. J Neuropathol Exp Neurol 26:25-39.

Heinonen O, Soininen H, Sorvari H, Kosunene O, Paljarvi L, Koivisto E, Riekkinen PJ (1995) Loss of synaptophysin-like immunoreactivity in the hippocampal formation is an early phenomenon in Alzheimer's disease. Neuroscience 64:375-384. 
Higgins LS, Holtzman DM, Rabin J, Mobley WC, Cordell B (1994) Transgenic mouse brain histopathology resembles early Alzheimer's disease. Ann Neurol 35:598-607.

Hirano A (1994) Hirano bodies and related neuronal inclusions. Neuropathol Appl Neurobiol 20:3-11.

Hof PR, Cox K, Morrison JH (1990) Quantitative analysis of a vulnerable subset of pyramidal neurons in Alzheimer's disease. I. Superior frontal and inferior temporal cortex. J Comp Neurol 301:44-54.

Hyman BT, VanHoesen GW, Damasio AR, Barnes CL (1984) Alzheimer's disease: cell-specific pathology isolates the hippocampal formation. Science 225:1168-1170.

Joachim CL, Mori H, Selkoe DJ (1989) Amyloid beta-protein deposition in tissues other than brain in Alzheimer's disease. Nature 341:226-230.

LaFerla FM, Tinkle BT, Bieberich CJ, Haudenschild CC, Jay G (1995) The Alzheimer's A beta peptide induces neurodegeneration and apoptotic cell death in transgenic mice. Nature Genet 9:21-30.

Lampert P (1967) A comparative electron microscopic study of reactive, degenerating, regenerating, and dystrophic axons. J Neuropathol Exp Neurol 26:345-368.

Lassman H, Bancher C, Breitschopf H, Wegiel J, Bobinski M, Jellinger K, Wisniewski HM (1995) Cell death in Alzheimer's disease evaluated by DNA fragmentation in situ. Acta Neuropathol 89:35-41.

Martin LJ, Pardo CA, Cork LC, Price DL (1994) Synaptic pathology and glial responses to neuronal injury precede the formation of senile plaques and amyloid deposits in the aging cerebral cortex. Am J Pathol 145:1358-1381.

Masliah E, Hansen L, Albright T, Mallory M, Terry RD (1991a) Immunoelectron microscopic study of synaptic pathology in Alzheimer's disease. Acta Neuropathol 81:428-433.

Masliah E, Mallory M, Hansen L, Alford M, Albright T, DeTeresa R, Terry RD, Baudier J, Saitoh T (1991b) Patterns of aberrant sprouting in Alzheimer's disease. Neuron 6:729-739.

Masliah E, Mallory M, Hansen L, Alford M, Albright T, Terry R, Shapiro P, Sundsmo M, Saitoh T (1991c) Immunoreactivity of CD45, a protein phosphotyrosine phosphatase, in Alzheimer's disease. Acta Neuropathol 83:12-20.

Masliah E, Ellisman M, Carragher B, Mallory M, Young S, Hansen L, DeTeresa R, Terry RD (1992) Three-dimensional analysis of the relationship between synaptic pathology and neuropil threads in Alzheimer's disease. J Neuropathol Exp Neurol 51:404-414.

Masliah E, Mallory M, Hansen L, Alford M, DeTeresa R, Terry R (1993a) An antibody against phosphorylated neurofilaments identifies a subset of damaged association axons in Alzheimer's disease. Am J Pathol 142:871-882.

Masliah E, Mallory M, Deerinck T, DeTeresa R, Lamont S, Miller A, Terry RD, Carragher B, Ellisman M (1993b) Re-evaluation of the structural organization of neuritic plaques in Alzheimer's disease. J Neuropathol Exp Neurol 52:619-632.

Masliah E, Mallory M, Ge N, Godson C, Saitoh T (1993c) Phorbol ester-induced neuritic alterations in the rat neocortex: structural and immunocytochemical studies. Mol Chem Neuropathol 20:125-145.

Masliah E, Honer WG, Mallory M, Voigt M, Kushner P, Terry RD (1994a) Topographical distribution of synaptic-associated proteins in the neuritic plaques of Alzheimer's disease hippocampus. Acta Neuropathol 87:135-142.

Masliah E, Mallory M, Hansen L, DeTeresa R, Alford M, Terry R (1994b) Synaptic and neuritic alterations during the progression of Alzheimer's disease. Neurosci Lett 174:67-72.

Masliah E (1995) Mechanisms of synaptic dysfunction in Alzheimer's disease. Histol Histopathol 10:509-519.

Mattson MP, Cheng B, Culwell AR, Esch FS, Lieberburg I, Rydel RE (1993) Evidence for excitoprotective and intraneuronal calciumregulating roles for secreted forms of the $\beta$-amyloid precursor protein. Neuron 10:243-254.

Mucke L, Masliah E, Johnson WB, Ruppe MD, Rockenstein EM, ForssPetter S, Pietropaolo M, Mallory M, Abraham CR (1994) Synaptotrophic effects of human amyloid $\beta$ protein precursors in the cortex of transgenic mice. Brain Res 666:151-167.

Munoz DG (1991) Chromogranin A-like immunoreactive neurites are major constituents of senile plaques. Lab Invest 64:826-832.

Murrell J, Farlow M, Ghetti B, Benson MD (1991) A mutation in the amyloid precursor protein associated with hereditary Alzheimer's disease. Science 254:97-99.
Nakagawa Y, Nakamura S, Kase Y, Noguchi T, Ishihara T (1987) Colchicine lesions in the rat hippocampus mimic the laterations of several markers in Alzheimer's disease. Brain Res 408:57-64.

Palmer AM, Gershon S (1990) Is the neuronal basis of Alzheimer's disease cholinergic or glutamatergic? FASEB J 2745:2752.

Perry EK, Perry RH, Blessed G, Tomlinson BE (1977) Neurotransmitter enzyme abnormalities in senile dementia: CAT and GAD activities in necropsy tissue. J Neurol Sci 34:247-265.

Pollard H, Charriaut-Marlangue C, Cantagrel S, Represa A, Robain O, Moreau J, Ben-Ari Y (1994) Kainate-induced apoptotic cell death in hippocampal neurons. Neuroscience 63:7-18.

Portera-Cailliau C, Hedreen JC, Price DL, Koliatsos VE (1995) Evidence for apoptotic cell death in Huntington's disease and excitotoxic animal models. J Neurosci 15:3775-3787.

Rockenstein EM, McConlogue L, Tan H, Power M, Masliah E, Mucke L (1995) Levels and alternative splicing of amyloid $\beta$ protein precursor (APP) transcripts in brains of APP transgenic mice and humans with Alzheimer's disease. J Biol Chem 270:28257-28267.

Roher A, Gray EG, Paula-Barbosa M (1988) Alzheimer's disease: coated vesicles, coated pits and the amyloid-related cells. Proc R Soc Lond [Biol]232:367-373.

Schochet SS, Lampert PW, Earle KM (1968) Neuronal changes induced by intrathecal vincristine sulfate. J Neuropathol Exp Neurol 27:645-658.

Selkoe DJ (1993) Physiological production of the $\beta$-amyloid protein and the mechanisms of Alzheimer's disease. Trends Neurosci 16:403-409.

Selkoe DJ, Podlisny MB, Joachim CL, Vickers EA, Lee G, Fritz LC, Oltersdorf T (1988) Beta-amyloid precursor protein of Alzheimer's disease occurs as 110- to 135-kilodalton membrane-associated proteins in neural and nonneural tissue. Proc Natl Acad Sci USA 85:7341-7345.

Seubert P, Vigo-Pelfrey C, Esch F, Lee M, Dovey H, Davis D, Sinha S, Schlossmacher M, Whaley J, Swindlehurst C, McCormack R, Wolfert R, Selkoe D, Lieberburg I, Schenk D (1992) Isolation and quantification of soluble Alzheimer's $\beta$-peptide from biological fluids. Nature 359:325-327.

Shelansky ML (1969) Neurofibrillary degeneration. Arch Neurol 20:199-206.

Sisodia SS, Koo EH, Beyreuther K, Unterbeck A, Price DL (1990) Evidence that $\beta$-amyloid protein in Alzheimer's disease is not derived by normal processing. Science 248:492-494.

Sloviter RS, Dean E, Neubort S (1993) Electron microscopic analysis of adrenalectomy-induced hippocampal granule cell degeneration in the rat: apoptosis in the adult central nervous system. J Comp Neurol 330:337-351.

Smale G, Nichols NR, Brady DR, Finch CE, Horton Jr WE (1995) Evidence for apoptotic cell death in Alzheimer's disease. Exp Neurol 133:225-230.

Southam E, Thomas PK, King RHM, Goss-Sampson MA, Muller DPR (1991) Experimental vitamin E deficiency in rats. Morphological and functional evidence of abnormal axonal transport secondary to free radical damage. Brain 114:915-936.

Su JH, Anderson AJ, Cummings BJ, Cotman CW (1994) Immunohistochemical evidence for apoptosis in Alzheimer's disease. NeuroReport 5:2529-2533.

Suzuki N, Cheung TT, Cai X-D, Odaka A, Otvos Jr L, Eckman C, Golde TE, Younkin SG (1994) An increased percentage of long amyloid $\beta$ protein secreted by familial amyloid $\beta$ protein precursor (beta APP717) mutants. Science 264:1336-1340.

Terry RD, Pena C (1965) Experimental production of neurofibrillary degeneration. II. Electron microscopy: phosphatase histochemistry and electron probe analysis. J Neuropathol Exp Neurol 24:200-210.

Terry RD, Wisniewski HM (1970) The ultrastructure of the neurofibrillary tangle and the senile plaque. In: Ciba Foundation symposium on Alzheimer's disease and related conditions (Wolstenholme GEW, O'Connor M, eds), pp 145-168. London: J. \& A. Churchill.

Terry RD, Gonatas NK, Weiss M (1964) Ultrastructural studies in Alzheimer's presenile dementia. Am J Pathol 44:269-297.

Terry RD, Peck A, DeTeresa R, Schechter R, Horoupian DS (1981) Some morphometric aspects of the brain in senile dementia of the Alzheimer type. Ann Neurol 10:184-192.

Terry RD, Hansen L, Masliah E (1994) Structural alterations in Alzheimer's disease. In: Alzheimer's disease (Terry RD, Katzman R, eds), pp 179-196. New York: Raven. 
Toggas SM, Masliah E, Rockenstein EM, Mucke L (1994) Central nervous system damage produced by expression of the HIV-1 coat protein gp120 in transgenic mice. Nature 367:188-193.

Wang D, Munoz DG (1995) Qualitative and quantitative differences in senile plaque dystrophic neurites of Alzheimer's disease and normal aged brain. J Neuropathol Exp Neurol 54:548-556.

Weiler R, Lassmann H, Fischer P, Jellinger K, Winkler H (1990) A high ratio of chromogranin A to synaptin/synaptophysin is a common feature of brains in Alzheimer's and Pick's disease. FEBS Lett 263:337-339.

Wilcock GK, Esiri MM, Bowen DM, Hughes AO (1988) The differential involvement of subcortical nuclei in senile dementia of Alzheimer's type. J Neurol Neurosurg Psychiatry 51:842-849.

Wisniewski H, Terry RD (1967) Experimental colchicine encephalopathy. I. Introduction of neurofibrillary degeneration. Lab Invest 17:577-587.

Wisniewski H, Terry RD (1970) An experimental approach to the morphogenesis of neurofibrillary degeneration and the argyrophilic plaque.
In: Ciba Foundation symposium on Alzheimer's disease and related conditions (Wolstenholme GEW, O’Connor M, eds), pp 223-248. London: J. \& A. Churchill.

Wisniewski H, Terry RD (1973) Re-examination of the pathogenesis of the senile plaque. In: Progress in neuropathology, Vol 2 (Zimmerman HM, ed), pp 1-26. New York: Grune \& Stratton.

Wisniewski H, Johnson AB, Paine CS, Kay WJ, Terry RD (1970) Senile plaques and cerebral amyloidosis in aged dogs. Lab Invest 23:287-296.

Wisniewski HM, Sinatra RS, Iqbal IY (1981) Neurofibrillary and synaptic pathology in aged brain. In: Aging and cell structure, Vol 1 (Johnson J, ed), pp 105-142. New York: Plenum.

Wisniewski HM, Wegiel J, Wang KC, Kujawa M, Lach B (1989) Ultrastructural studies of the cells forming amyloid fibers in classical plaques. Can J Neurol Sci 16:535-542.

Wisniewski HM, Barcikowska M, Kida E (1991) Phagocytosis of $\beta / \mathrm{A} 4$ amyloid fibrils of the neuritic neocortical plaques. Acta Neuropathol 81:588-590. 